\title{
Taipei and Seoul's Modern Urbanization under Japanese Colonial Rule: A Comparative Study from the Present-Day Context
}

\author{
Yeonkyung Lee \\ Institute of Convergence Research Institute of Regional Humanities and Information, Incheon National \\ University, Incheon 21999, Korea; yk1227@gmail.com; Tel.: +82-10-5019-5372
}

Received: 29 April 2020; Accepted: 7 June 2020; Published: 11 June 2020

\begin{abstract}
Both Taipei and Seoul underwent a process of colonization and modern urbanization during the early part of the 20th century, under Japanese rule. In both countries, urban-planning projects from the colonial period have had a great impact on recent urban changes. This comparative analysis aims to identify the characteristics of modern cities with Japanese colonial histories, focusing on the following three aspects: (1) Urban structure based on spatial distribution by ethnic group; (2) Japanese colonial urban planning; and (3) modern boulevards that convey the power and spectacle of a colonial city. Taipei and Seoul have multi-cores because the Japanese and Taiwanese/Korean areas were not clearly separated spatially. Secondly, Japanese colonial urban planning was influenced by Japanese settlements and government facilities. Thirdly, the main boulevards in each city, created through modern urban planning, combine modern streetscapes with imperial spectacle. These boulevards took on an important political meaning after liberation. Comparative studies of Taipei and Seoul can illuminate the difference between modern cities with a Japanese colonial history and colonial cities under European rule. Such comparisons make it possible to analyze the meaning, value, and relevance of colonial remnants, including urban structure and artifacts, for each city's sustainable future.
\end{abstract}

Keywords: Seoul; Taipei; modern urbanization; colonization; colonial modern city; colonial modernity; Japanese settlement; urban planning; modern boulevard

\section{Introduction}

\subsection{Background and Purpose of Research}

Taiwan and Korea became the first and second colonies of the Japanese Empire at the turn of the 20th century and during its early years, respectively. After the Asia-Pacific War, both nations were liberated from Japanese rule. Shortly afterwards, the two countries endured the Chinese Civil War and Korean War. During the post-war 1960s and 1970s, under strong national authorities, both countries achieved explosive economic growth [1] (p. 14). Taipei and Seoul experienced parallel dramatic changes, evolving from traditional walled cities into colonial modern cities, and from colonial cities to capitalist cities. The two cities have many similarities. Both were official capitals of Japanese colonies, which became modern cities via Japanese intervention. Following colonial rule, both underwent dramatic historical, political, and social changes during the 20th century [2-5]. As a result, the cityscapes and urban ambience of Seoul and Taipei are very much alike. However, the historical context after liberation caused Korean and Taiwanese people to have different attitudes toward the Japanese: Most Koreans are still hostile to the Japanese, however, Taiwanese attitudes toward Japan are complicated due to memory of the KMT(Kuomintang, Chinese Nationalist Party) [6]. This has influenced the preservation and regeneration of these urban environments. For example, the demolition of residential buildings constructed during the Japanese colonial period has been a 
major issue in both Taipei and Seoul $[7,8]$. The Japanese Government-General of Taiwan (hereafter, JGGT) building is still used as the president's office, while the Japanese Government-General of Korea (hereafter, JGGK) building was destroyed in 1996.

What factors have caused the similarities and differences between the past and present urban environments of Taipei and Seoul? As Kim Baekyoung has pointed out, Japanese colonial cities, including Seoul, differ from colonial cities under European rule [4] (pp. 156-160). What are these differences, and why are Japanese colonial cities different? To answer these questions, this study investigates modern urbanization processes in Seoul and Taipei in connection with Japanese colonization in the 20th century. Specifically, it analyzes the characteristics of Taipei and Seoul as modern cities with a Japanese colonial history, focusing on urban structure, planning, and space. Focusing on the Japanese settlement and modern urban boulevard as the cause and effect of colonial urban planning, this study would expand the precedent comparative studies on the technical and systematic characteristics of colonial urban planning $[9,10]$. It argues that the tenets of colonial modernity, a post-colonial theory linking colonialism and modernity in non-European countries, are revealed through urban structures and spaces built during the colonial era [11].

The present study aims to understand how urban planning in the colonial era has affected these present-day cities. By investigating efforts made to overcome memories of colonization in urban spaces after liberation, it examines the ironies of a situation in which colonial traces continue to influence post-colonial urban spaces. To reevaluate urban environments constructed under Japanese imperialism in the context of sustainable urban development, it is essential to understand the historical context of both cities. In particular, a comparative analysis of modern colonial cities such as Taipei and Seoul, which have undergone similar processes during the 20th century, can shed light on both the common characteristics of modern cities with Japanese colonial histories, and the specific conditions in each city.

\subsection{Literature Review}

In urban studies of Taipei and Seoul, the representative studies on the comparative analysis of two cities is Goto Yasushi's (五島寧) comparative studies on urban improvement projects of Seoul and Taipei $[9,10]$. He pointed out the differences between the urban improvement projects of Taipei in 1905 and Seoul in 1912: The urban improvement project of Seoul aimed to construct the roads, however, in Taipei, the improvement works were executed to enhance sanitary conditions. [9] In the recent research, he found out that the urban planning of Korea and Taiwan in the 1930s was based on the City Planning Act of 1919 and the Urban Area Building Act of 1919 in Japan. His research focused on the urban planning projects of Taiwan, Korea, and Japan comparatively; however, the urban conditions before colonization, and the urban projects by Taiwanese/Korean government were not dealt with in his studies. It has resulted that the urban changes of Taipei and Seoul in the first half of twentieth century were strictly understood as a product of Japanese colonization. The other research is limited to brief references to research on each city [4] (p. 188), [12] (p. 227), [13] (p. 129).

By contrast, there is abundant research on the nature and meaning of the urban-transformation process in the context of each city. In Taipei studies, most researchers, including Koshizawa Akira (越沢明) [13], Huang Wuta (黃武達) [14], Goto Yasushi (五島寧) [15], Wu Pingsheng (吳秉聲) [16], Su Shuobin (蘇碩斌) [2], and Joseph R. Allen [3], have analyzed the modernization process of Taipei under Japanese colonial rule. Unlike previous studies, which focused on spatial transformation, Wu Ping-Sheng has focused on relationships between space/place and the colonizer/colonized from the perspectives of coloniality and modernity, analyzing the boulevard, arcade, and department store as places to walk around, which also exhibit imperial power [16]. By contrast, Joseph R. Allen has interpreted urban changes in Taipei since the late 19th century as a process of displacement, caused by the fluctuation of political power [3].

In Seoul studies, Sohn Jongmok's research $[17,18]$ provided basic information on the city's urban-transformation process, from the late 19th century onwards. Following on from his pioneering research, studies by Lee Taejin [19] and Kim Gwangwoo [20] have explored the process and meaning of 
the urban planning carried out in Seoul by Koreans prior to colonization. Based on precedent research on the urban-transformation process and urban planning in Seoul, Kim Baekyung [4] has focused on the way in which diverse aspects of urban planning, including the dual-city structure, urban infrastructure, and urban spaces (including the boulevard and urban plaza), related to people's everyday experiences and the imperial spectacle of colonial power. Yum Bokkyu [5] has investigated the ways in which diverse stakeholders viewed and responded to urban planning, while also researching the spatial characteristics of urban planning in colonial Seoul. Todd. A. Henry [21] has focused on the reactions of ordinary Korean and Japanese people to changes in urban public spaces made by the Japanese empire. In opposition to the theory of the colonial dual city [4,22,23], Kim Jonggeun [24] has disputed the colonial duality of Seoul, pointing that a census analysis reveals various types of residential area, including mixed Korean and Japanese areas, Chinese ghettos, and Japanese/Korean-dominated areas.

In sum, the existing literature on Taipei and Seoul under Japanese colonial rule can be categorized into analyses of urban planning and the urban-transformation process from a historical perspective, studies that detail the relationship between urban spaces and colonial power, and those that investigate the experiences of urban dwellers in colonial modern cities from a socio-cultural perspective (Table 1).

Table 1. Themes in the existing literature.

\begin{tabular}{ccc}
\hline Theme & Taipei & Seoul \\
\hline & Koshn Jong-Mok & Lee Taejin \\
Urban Planning & Goto Yasushi & Kim Gwangwoo \\
& Huang Wuta & Kokkyu \\
Urban-transformation Process & Huang Wuta & Todd. A. Henry \\
& Wu Pingsheng & Kim Baekyung \\
Urban Space and Colonial Power & Su Shuobin & Yum Bokkyu \\
Experiences of the Inhabitants of Modern Colonial Cities & Joseph R. Allen & Todd. A. Henry \\
\hline
\end{tabular}

\subsection{Research Materials and Methods}

This study draws on archival research to analyze the urbanization process in Seoul and Taipei during the twentieth century. The following major studies address the modern transformation process in each city. In the field of Taipei studies, Akira Koshizawa [13], Goto Yasushi [15], Su Shuobin [2], and Joseph R. Allen [3] have analyzed the urban-transformation process in Taipei; Wu Pingsheng's [14] distinguished analysis of the colonial modern city, Taipei, incorporates the concept of walking on the modern boulevard. In the field of Seoul studies, key research on the construction of colonial Seoul includes Kim Jonggeun's [24] critical discussion of the colonial duality, Yum Bokkyu's [5] analysis of the background and process of urban planning in Seoul, Kim Baekyung's [4] analysis of the relationship between imperial power and urban space, and Todd Henry's [21] writings on the modern boulevard.

The present study focuses on the following three aspects of comparative research on Taipei and Seoul:

1. Urban structure, based on analyses of the colonizer/colonized distribution, which affected urban planning in both cities.

2. Urban planning carried out by the Japanese empire, which played a significant role in building the colonial modern cities of Taipei and Seoul.

3. Modern boulevards, which present the spectacle of colonial cities, as a consequence of modern urban planning carried out by the colonizer.

The present study begins by analyzing the influence of Japanese residential areas on urban structure through a statistical and mapping analysis of Japanese and Taiwanese/Korean census data for each city. Colonial-era census data have been drawn from Historical Demography [25], the Taiwan Database for Empirical Legal Studies [26], Taihokushitoukeisho [2,27], the Korean Statistical Information Service [28], and Chosenshowajyunenkokujeichosasho [29,30]. 
Second, imperial Japanese urban-planning projects played a pivotal role in transforming Taipei and Seoul into colonial modern cities. The present study uses historical documents and maps to analyze and compare their colonial characteristics, with a particular focus on the Municipal Reform Project for Taihoku City (台北市區 [31] 計畫) and Keijo Urban Improvement Planning in 1912 and 1919. The following historical manuscripts and maps have been used to analyze urban-planning projects in Taipei and Seoul: Taihokujyunenshi (台北市十年誌) of 1930, Taihokushiseinijyunenshi (台北 市政二十年史) of 1940 [30], Taipeishizhi (臺北市志) of 1997 [32], Keijotoshikeikakuchosasho (京城都市計 劃調査書) of 1927 [33,34], Keijofushi (京城府史) of 1934 [35], Seoulyukbaeknyeonsa (서울六百年史) of 1981 [36], City Planning Plan of Inner Taihoku City (台北城内市街計畫) of 1900 [37], the Municipal Reform Project Plan for Taihoku City (臺北市區改正圖) of 1905 and 1907 [37], A Map of Keijo (京城市街圖) from 1907 [38], and the Keijo Urban Improvement Planning Map (京城市區改修豫定計畫路線圖) from 1912 and $1919[39,40]$.

Third, the modern boulevards of Taipei and Seoul, as representative urban spaces in colonial modern cities, are analyzed in connection with modern streetscapes and imperial power, through an analysis of historical photographic images, accessed via the digital archives of the Map and Remote Sensing Imagery Digital Archive Project [37], Taiwan Memory [41], the Seoul Museum of History [38], and the Seoul Research Data Service [42].

\section{Background: Taipei and Seoul before Colonization}

\subsection{Taipei before Japanese Colonization}

In the late 19th century, Taipei became the political and commercial center of Taiwan. After Damsui (淡水) became an open port in 1860, the northern part of Taiwan Island developed rapidly. In 1875, the northern part of Taiwan Island was separated from Taiwan Prefecture to create Taipeifu (府)', the new Qing Prefecture. In 1879, construction began on the Taipei City Wall, which was completed in 1884. In 1891, Taipeifu City became the Qing provincial capital. Taipeifu City was located in a paddy field between the original settlements of Dadaocheng (大稻埕) and Banka (艋舺 (present-day Wanhua (萬 華)), which developed after the mid-19th century. An empty field was chosen as the site for Taipeifu City because conflicts between the settlers of Dadaocheng and Banka made it impossible to choose either settlement [43] (pp. 253-258). With the construction of Taipeifu City and the development of Dadaocheng and Banka, the Taipei Basin entered the so-called Sanshijie (三市街, three settlement) period [14] (p. 101) (Figure 1).

Although the Taipei City Wall was planned as a rectangular construction, following Zhu Li Kao Gong Ji (The Rites of Zhou, 周禮考工記), the inner roads did not run parallel to the city walls. During the first stage of Taipeifu City construction, Taipei was planned as a northwestern-facing square city. Between 1879 and 1881, the main streets, including Fuho, Fuqian, and Fuzhi Streets, were built. Public buildings, including the Taipei prefectural office (fu yamen), official residential hall, Confucian temple, prefectural and county City God temple, examination hall, and the office of the Taipei prefectural director of studies, were built. After Liu Ao (劉璈) handed over the city wall project in 1882, he changed the original position of the Taipei City Wall to reflect feng-shui theory. Consequently, the position of the Taipei City Wall moved slightly southwest. The location of the five gates was determined in accordance with the principles of feng-shui, as well as defense, and practical communication demands. The est and Auxiliary South Gates led to Banka, while the North Gate led to Dadaocheng. The South and East Gates led to the eastside farming areas [44] (pp. 82-88), [16] (pp. 102,103).

After 1885, the Governor of Taiwan, Liu Ming-Ch'uan, set about constructing the urban infrastructure of Taipei. He constructed railroads between Jiloong and Xinju; several new paved streets, including Ximen and Beimen Streets; a drainage system; and several public buildings, including Yamen (the Provincial Governor's Office) and educational and religious buildings. In addition, he moved the northern military headquarters from Banka to the inner city. Most public facilities were concentrated 
in the northwest area of the city; there were only a few educational facilities in the northeast and a few military buildings and shrines in the south. As a map of 1895 makes clear (Figure 2), the center of Taipeifu City was the northwestern area, where the main public facilities were located, with connections to Dadaocheng and Banka. The southeastern part of the city remained relatively vacant, until 1895, when the Japanese occupied Taiwan [16] (pp. 101-107).

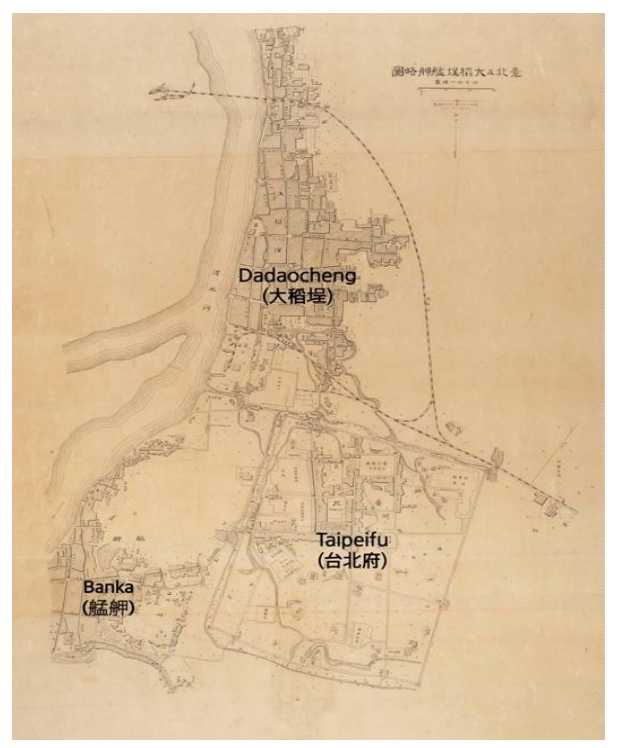

Figure 1. The Sanshijie system in the Taipei area in 1895 (source: Author's edit. National Taiwan Museum.

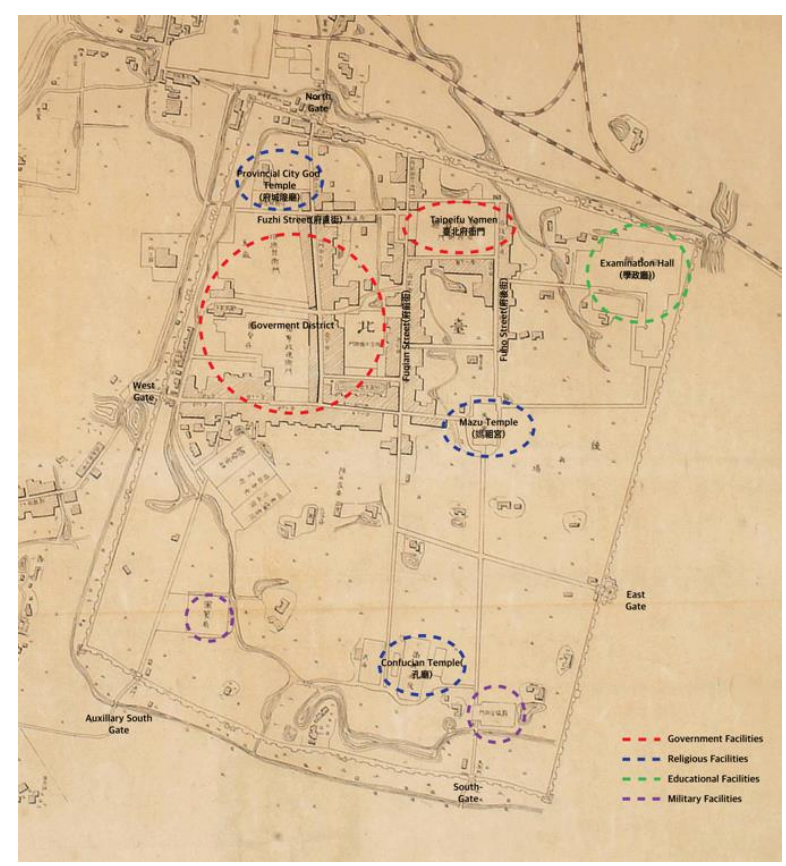

Figure 2. Spatial structure of Taipei inner city in 1895 (source: Author's edit. National Taiwan Museum [45]).

\subsection{The Spatial Structure of Seoul, the Traditional City of Joseon Dynasty}

Seoul has been the capital of Korea since 1394, when Lee Sung Gye, the first king of the Joseon Dynasty (a kingdom of Korea from 1394 to 1897) moved the seat of government from Kaegyeong 
(present-day Kaesung) to Seoul. Since then, the city has been the political, social, economic, and cultural center of Korea. After Japanese colonization, the Japanese Empire renamed Seoul “Keijofu” (京城府), instead of Hansungbu (漢城府), its official name during the Joseon dynasty [34-36].

Seoul lies in a basin surrounded by four mountains in the cardinal directions. It was constructed as a traditional walled city, with four main gates and four small gates connecting the inner city and the outskirts. In the central-northern part of Seoul, there are two main palaces: Gyeongbok Palace and Changdeok Palace. Jongro Street, in the center of the city, forms the main east-west axis linking the East Gate to the West Gate. For reasons of geography and feng-shui theory, Seoul has no central north-south axis. Instead, there are two main streets: Namdaemunro Street, which connects Jongro Street to the South Gate, and Yukjo Street (present-day SeJongro Street), which connects Jongnro Street to Gyeongbok Palace. Yukjo Street was the political and administrative center of Seoul, lying in front of the main palace of Joseon Dynasty; the name refers to six government offices. Jongro and Namadaemun Streets were commercial and social centers, with many shops. Namdaemunro Street led to Yongsan, on the southern outskirts of Seoul, with a river port through the South Gate. Jongro Street led to Mapo, the city's south-western river port, through the West Gate. As Figure 3 shows, the main facilities, including palaces, shrines, and government offices, were located on the northern side of Jongro Street, while commercial facilities were located along Jongro and Namdaemun Streets, Chunggye Stream, and outside the South and West Gates. Most nobles and members of the royal family lived in the Bukchon (the northern part of Seoul), to the north of Chunggye Stream. Impoverished nobles and the middle classes lived in Namchon (the name means "southern village on the Namsan hills"). Bukchon had a much better environment than Namchon, because the area was well-drained, with abundant sunlight and easy access to urban centers [34-36].

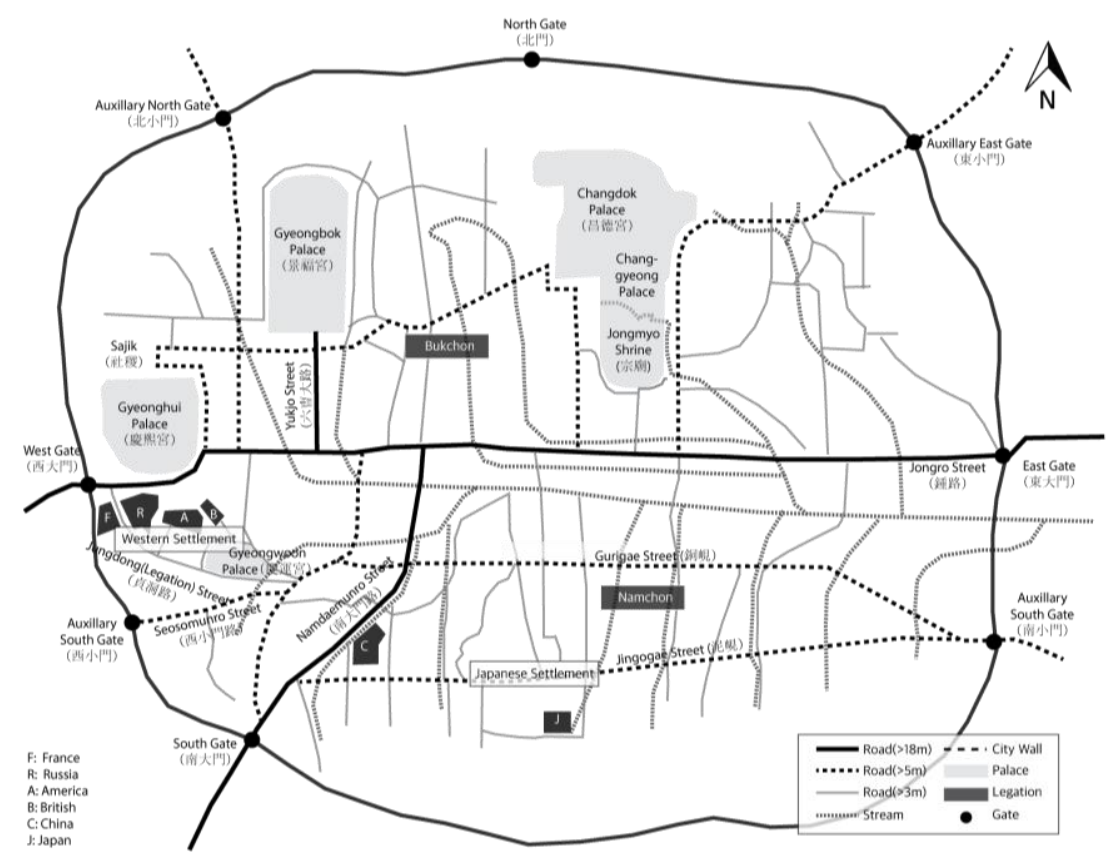

Figure 3. The spatial structure of Seoul around 1900. (Source: Author, base map: Hanyanggyeongsungdo (漢陽京城圖), 1900 [38]).

The population of Seoul has been increasing since the 17th century, while the urbanization and commercialization of Seoul have progressed rapidly. After the port opened to foreign countries in 1876, Western civilization began to influence the city. After 1882, foreigners were permitted to live in Seoul. During the 1880s, foreign legation buildings were constructed in western and southern parts of Seoul. Westerners lived in Jeongdong District, near Gyeongwoon Palace. Chinese residents lived in the southern part of the city around Supyo Bridge, close to Jongno Street (the main shopping 
street of Seoul). The Japanese lived in Jingogae District, the northern part of Namsan Hill, which, unlike the Jeongdong and Supyo Bridge areas, had no political or economic advantages. Before the 1880s, there were only one-story Korean traditional buildings in Seoul. As foreigners began to live in the city, they introduced foreign-style buildings in their own residential areas. Red-brick multistory buildings appeared in Seoul. Although there were only a few such buildings, the construction of foreign residences changed the cityscape. Moreover, a growing population and increased population density degraded the urban environment. For this reason, discussions between foreigners and the Korean government began during the late 19th century on the need to introduce modern urban infrastructure and urban planning [46-48].

\section{Comparison of Urban Changes in Seoul and Taipei as They Became Modern Colonial Cities 1: The Growth of Japanese Settlements and the Formation of Mixed Residential Areas}

Before the Japanese occupation, Taipei and Seoul were walled cities built in accordance with traditional Chinese principles of city construction. Both cities had city gates facing north, south, east, and west. Government facilities were in the northern part of both cities. However, these two cities were fundamentally different. The original civic center of Seoul was inside the city wall, while the original urban settlements of Taipei were outside the city wall; inner-city Taipei had been built as a new Taipei-area civic center in 1879. In 1895, the Japanese empire established JGGT in the Taipei inner city. In 1910, Seoul finally became a Japanese colonial city, 28 years after Japanese settlers first invaded the southern part of Seoul. Thus, the colonization process of Taipei overlapped with the construction of a new town in the vacant south-east area of inner-city Taipei. By contrast, the transformation of Seoul into a colonial modern city began with the invasion of Japanese settlers, building into a gradual expansion into the traditional civic center.

After Japanese colonization in 1895, the population of Taipei increased rapidly. Specifically, the population of Taipei inner city, where the population grew fastest, tripled, rising from 3895 in 1896 to 11,370 in 1905. The population of the original settlements of Banka and Dadaocheng also increased. The total number of residents in the Taipei area, including the inner city, Banka, and Dadaocheng, doubled, growing from 46,710 in 1896 to 99,479 in 1905. The Japanese population, in particular, soared from 4256 in 1896 to 29,460 in 1905 (a sevenfold increase) [26,31]; as a proportion of the total population, the Japanese population grew from $9.1 \%$ to $29.6 \%$ in 10 years. During the early stage of the Japanese occupation, almost $73 \%$ of Japanese residents lived in the Taipei inner city. By 1905, however, the Japanese population of Banka exceeded that of Taipei inner city, due to the construction of a Japanese residential district outside the city wall, based on "City Planning of Southern Area outside Taihoku City" (台北城外南方市區計畫) in 1901. However, the population in Taipei inner city was predominantly Japanese: $72.8 \%$ in $1896,87.2 \%$ in 1902 , and $88.6 \%$ in 1905 [25,26,31]; Taipei census data before and after the turn of the 20th century (Table 2) show that Taipei inner city was a Japanese-dominated area, while the southern outskirts of Taipei inner city gradually became a mixed-residence quarter, with Taiwanese and Japanese residents.

Table 2. Taipei area demographics by ethnic group in 1896, 1902, and 1905.

\begin{tabular}{|c|c|c|c|c|c|c|c|}
\hline \multirow{5}{*}{ Taipei Inner City } & \multirow{4}{*}{$\begin{array}{c}\text { Ethnic Group } \\
\text { Total } \\
\text { Taiwanese } \\
\text { Japanese }\end{array}$} & \multicolumn{2}{|c|}{$1896[28]$} & \multicolumn{2}{|c|}{$1902[23]$} & \multicolumn{2}{|c|}{1905 [24] } \\
\hline & & 3815 & & 8323 & & 11,370 & \\
\hline & & 1036 & $27.2 \%$ & 880 & $10.6 \%$ & 1110 & $9.8 \%$ \\
\hline & & 2779 & $72.8 \%$ & 7258 & $87.2 \%$ & 10,071 & $88.6 \%$ \\
\hline & Western & - & - & 185 & $2.2 \%$ & 189 & $1.7 \%$ \\
\hline \multirow{4}{*}{ Banka } & Total & 19,711 & & 29,727 & & 34,308 & \\
\hline & Taiwanese & 18,745 & $95.1 \%$ & 23,828 & $80.2 \%$ & 17,700 & $51.6 \%$ \\
\hline & Japanese & 966 & $4.9 \%$ & 5338 & $18.0 \%$ & 13,823 & $40.3 \%$ \\
\hline & Western & - & - & 561 & $1.9 \%$ & 2785 & $8.1 \%$ \\
\hline \multirow{4}{*}{ Dadao cheng } & Total & 23,184 & & 50,897 & & 53,801 & \\
\hline & Taiwanese & 22,673 & $97.8 \%$ & 46,914 & $92.2 \%$ & 43,424 & $80.7 \%$ \\
\hline & Japanese & 511 & $2.2 \%$ & 1673 & $3.3 \%$ & 5566 & $10.3 \%$ \\
\hline & Western & - & - & 2310 & $4.5 \%$ & 4811 & $8.9 \%$ \\
\hline
\end{tabular}


Although Japanese people began living in Seoul in 1882, there were only 40 Japanese residents at that time. After the Sino-Japanese war, the Japanese population more than doubled, from 848 in 1895 to 1839 in 1896. After the Russo-Japanese war, the Japanese population was more than 10,000 in 1906 and 34,468 in 1910 [48] (pp. 105-107). As the number of Japanese residents increased, the Japanese settlement area also expanded to include the southern area of Seoul and the Yongsan area, outside the Seoul city wall. Yongsan grew into the second Japanese settlement in Seoul after the Russo-Japanese war. The Japanese army took a large amount of land in Yongsan for military use and the construction of a railway in 1904. They built many facilities around the railway, including a railway station, hospital, school, and official residences. The population of Japanese residents in Yongsan increased rapidly from 1904 onwards. In 1904, the Japanese population consisted of 350 people. By 1905, it had increased to 1700, while in 1909, it was more than 10,000 [49] (pp. 92-93). Table 3 shows the demographics of Seoul by ethnic group in 1911 and 1913, following Japanese occupation. In 1911, there were 35,268 Japanese settlers-15.8\% of the total population of Seoul inner city; in Yongsan, 59.6\%of the total population was Japanese.

Table 3. The demographics of Seoul by ethnic group in 1911 and 1913.

\begin{tabular}{|c|c|c|c|c|c|}
\hline Region & Ethnic Group & & & & \\
\hline \multirow{5}{*}{ Kyungsung Inner City } & Total & 223,381 & & 228,170 & \\
\hline & Korean & 185,898 & $83.2 \%$ & 183,240 & $80.3 \%$ \\
\hline & Japanese & 35,268 & $15.8 \%$ & 42,841 & $18.8 \%$ \\
\hline & Chinese & 1963 & $0.9 \%$ & 1781 & $0.8 \%$ \\
\hline & Foreigners & 252 & $0.1 \%$ & 308 & $0.1 \%$ \\
\hline \multirow{5}{*}{ Yongsan } & Total & 17,307 & & 23,209 & \\
\hline & Korean & 6974 & $40.3 \%$ & 11,127 & $47.9 \%$ \\
\hline & Japanese & 10,319 & $59.6 \%$ & 12,049 & $51.9 \%$ \\
\hline & Chinese & 11 & $0.1 \%$ & 31 & $0.1 \%$ \\
\hline & Foreigners & 3 & $0.0 \%$ & 2 & $0.0 \%$ \\
\hline
\end{tabular}

The distribution of Japanese settlements in Taipei and Seoul affected the urban structure of the two cities. In Taipei, the colonizer's initial urban-planning project focused on Taipei inner city, where the colonial government was located, and most Japanese settlers lived. After 1905, urban planning in Taipei focused on creating an integrated urban system to link the Taiwanese-dominated areas of Banka and Dadaocheng with the Japanese area in inner-city Taipei by demolishing the city wall and building roads to connect the three urban centers of Taipei, Banka, and Dadaocheng with the inner city. As this was happening, the Japanese population of Banka and Dadaocheng continued to increase.

The growth of Yongsan transformed the spatial structure of Seoul. Yongsan was linked to the outer old Seoul (城底十里) and located on the south-west side of Seoul. When the modernization and colonization process began, Yongsan became a center for railway transportation and the second Japanese settlement in Seoul. It was necessary to enhance transportation conditions by improving the road between Yongsan and the South Gate of Seoul and tearing down part of the Seoul city wall around the South Gate. The 1912 urban improvement plan included the road toward Yongsan; in 1914, greater Seoul officially included the Yongsan area [35] (p. 442). Thus, Seoul became characterized by an urban structure in which a new town protruded from the traditional walled city, resembling the typical colonial dual cities of Delhi and New Delhi [4] (p. 188).

The residential areas allocated to the colonizer and colonized were not clearly divided into Taipei and Seoul, in contrast to Western colonial cities [24]. Figure 4 shows the distribution of the Japanese population in Taipei in 1932 [2,27] and Seoul in 1935 [29,30]. In Taipei, Japanese people dominated the entire Taipei inner city (A), while the proportion of Japanese people was high in both areas between Dadaocheng and Banka (B) and also on the east side, adjacent to the former Taipei inner city wall (C), constructed after the initial period of urban planning in 1905. The remaining area was dominated by Taiwanese people. However, the ratio of Japanese people in Ohashicho (大橋町, D) was relatively high $(62.61 \%)$ in comparison to its neighbors; the south-eastern (E) and north-eastern parts of Taipei (F) 
were mixed residential areas [2]. In Seoul, Japanese people were dominant in Namchon (a) in the Seoul inner city, and also in the Yongsan area (b). However, the villages around the former West Gate (c), Gwanghwamun Street (d), and Keijo University (e) constituted a mixed residential area.

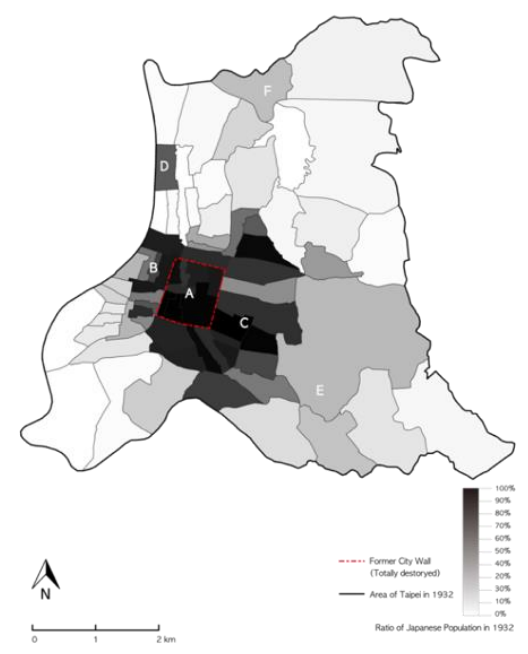

(a)

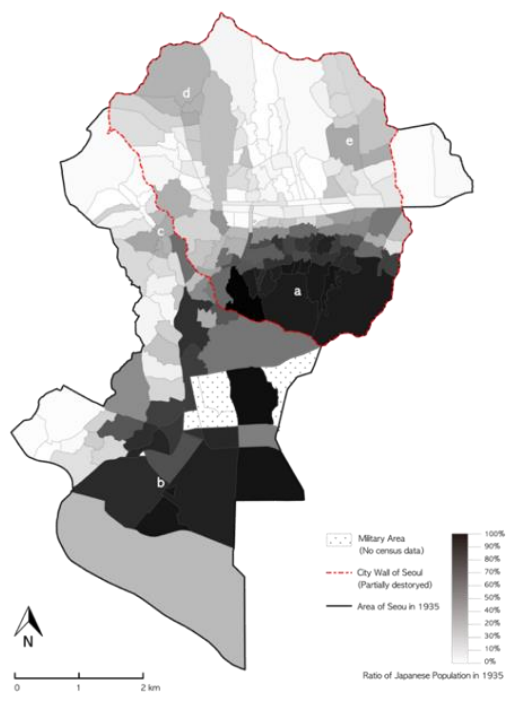

(b)

Figure 4. (a) The Japanese population of Taipei in 1932 (source: Author) (b) the Japanese population of Seoul in 1935 (source: Author).

In conclusion, there was no apparent spatial separation by ethnic group in Taipei or Seoul. Both cities appeared to have three types of residential district: Japanese-dominated new towns, mixed Japanese and Taiwanese/Korean districts, and Taiwanese/Korean-dominated areas. Japanese colonial cities were unique in having large colonizer populations (Japanese people) from a range of social and economic classes. In Taipei and Seoul, Japanese people accounted for almost $30 \%$ of the whole population). Unlike colonizer populations in colonial cities under European rule, Japanese people looked very similar to colonized Koreans and Taiwanese.

\section{Comparison of Urban Changes in Seoul and Taipei as They Became Modern Colonial Cities 2: Urban Planning}

In 1895, the first urban-improvement projects were undertaken in both cities; however, different agents carried out these projects in Taipei and Seoul. This reflected the fact that Taipei was newly colonized in 1895, as a consequence of the first Sino-Japanese war, while Seoul was still independent at that time.

In 1895, Taipei was renamed "Taihoku" (台北) by the Japanese authorities. During the first ten years of colonization, the Japanese focused on rebuilding and improving buildings and streets. In 1895, drains were temporarily set up along the outer city walls; in 1896, an open sewage system was installed along the inner streets of Taipeifu City. While urban changes between 1895 and 1899 emphasized improvements to urban sanitation and safety, urban planning after 1900 was characterized by the introduction of new block systems in Taipei and the construction of Japanese residential areas on the southeastern side of Taipei (Figure 5). In 1901, “City Planning for the Southern Area outside Taihoku City" (台北城外南方市區計畫), a plan for constructing a Japanese residential district, was extended to accommodate the increasing Japanese population [16] (pp. 119-120). 


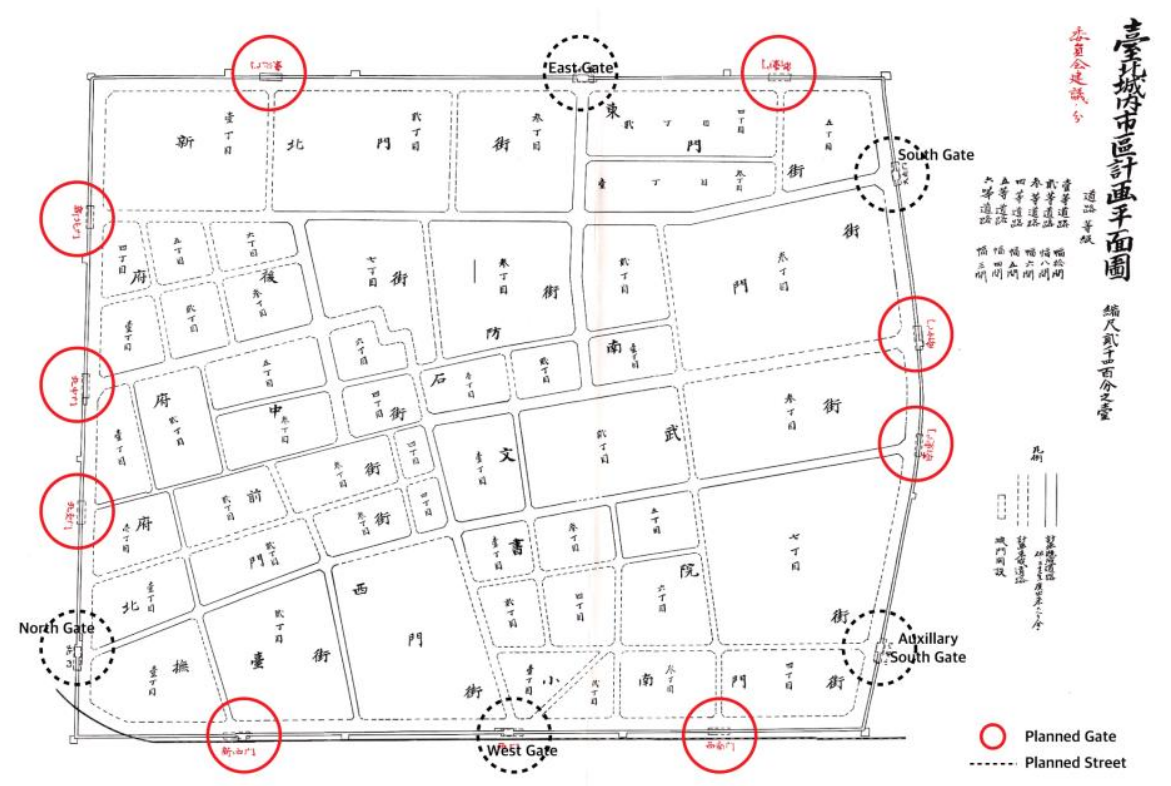

Figure 5. City planning plan for inner Taihoku City (source: Author's edit. The Map and Remote Sensing Imagery Digital Archive Project [37]).

In 1895, the Seoul government began to improve city roads and to build new ones, beginning its urban-improvement activities by demolishing illegal buildings on Namdaemunro and Jongno Streets in 1895. In 1896, Namdaemun and Jongno Streets were repaired and the roads around Gyeongwoon Palace, which became the main palace of the Daehan Empire after 1897, were improved. As urban-improvement projects were implemented between 1895 and 1897, the road system around Gyeongwoon Palace was constructed and readied for the introduction of new transportation facilities, such as trams in 1899. After 1901, however, the government's urban-improvement projects had to stop, due to financial difficulties $[46,47]$. At the same time, Westerners repaired the main street of Jeongdong, where legations were based, while the Japanese improved streets in the Japanese settlement area. Japanese urban-improvement projects continued, as needed, until 1910 [48] (p. 211-212) (Figure 6).

The urban planning projects that led to the construction of colonial modern cities were announced for Taipei and Seoul in 1905 and 1912, respectively. In 1905, the Municipal Reform Project for Taihoku City (台北市區計畫) was announced. This urban-planning project was the first to cover the whole Taipei area, including the original settlement, Dadaocheng, and Banka. It aimed to cover 720 hectares of urban land, as the population was predicted to reach 150,000 by 1929. In this plan, the city walls were replaced with a 37-72 $\mathrm{m}$ ring boulevard. The inner-city grid street patterns were extended to the outer regions, while several roundabouts were planned as special nodes. The existing roads of Dadaocheng and Banka were to be straightened, with radial streets superimposed at some nodal points [16] (p. 120), [3] (p. 31,32) (Figure 7). 


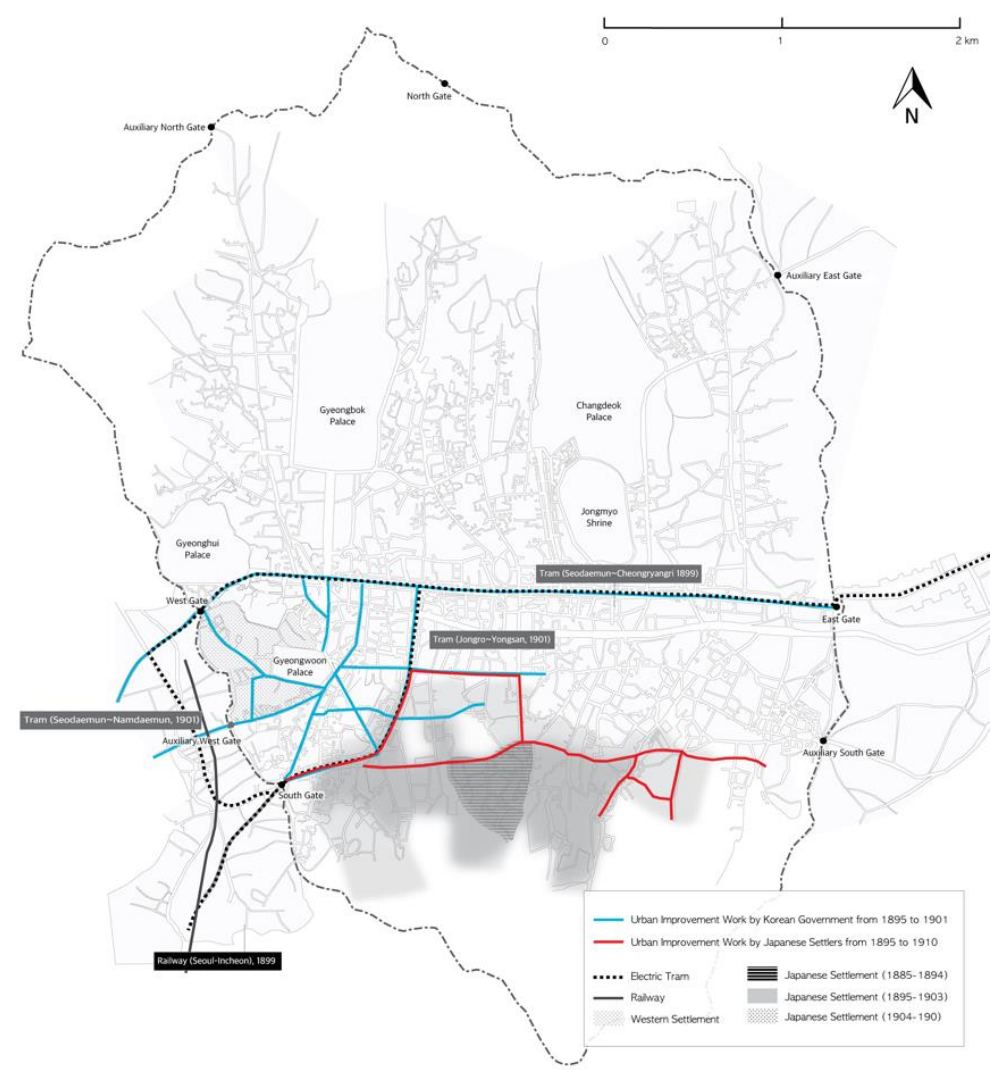

Figure 6. Urban-improvement projects of the Seoul government between 1895 and 1901 (source: Author's edit. Seoul Museum of History [38]).

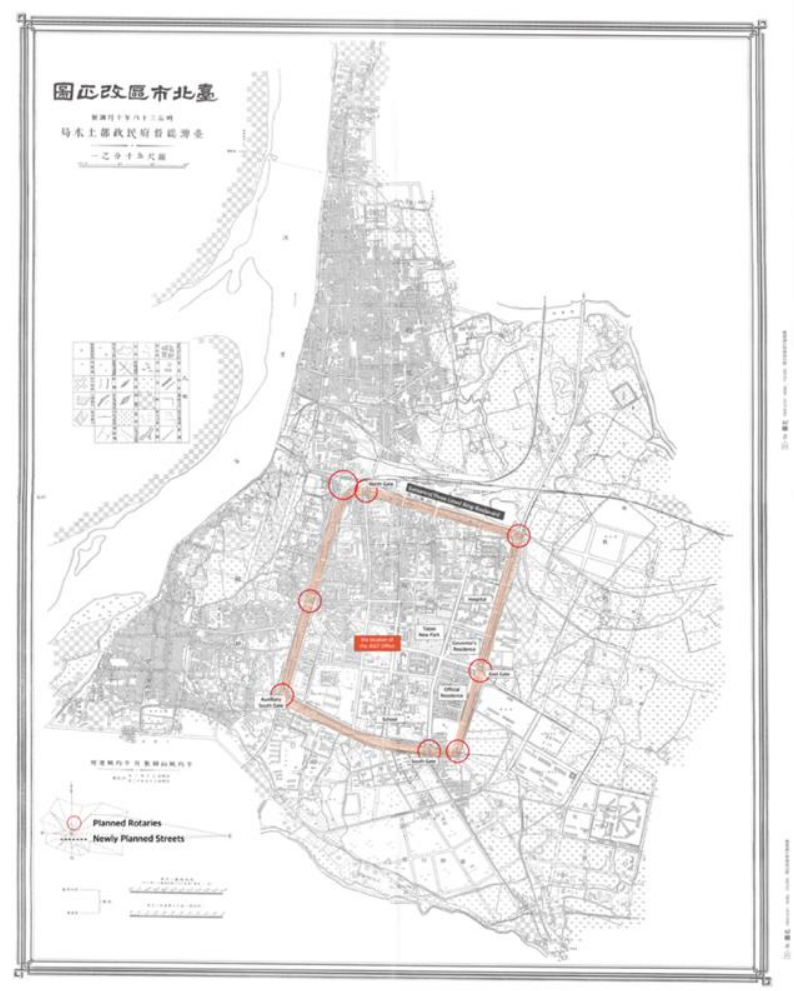

Figure 7. Municipal reform project for Taihoku City (台北市區計畫) in 1905 (source: Author's edit. The Map and Remote Sensing Imagery Digital Archive Project [37]). 
The distinguishing characteristic of this plan was the demolition of the city walls. The Taipei city walls, completed in 1884, had become an obstacle to urban growth within a mere ten years. Between 1910 and 1913, the site of the city walls was replaced with three-lined boulevards. During the initial stage of urban planning to enlarge Taipei City, five city gates were in line be demolished. In the end, only the West Gate was removed because some Japanese officials and members of the Chinese elite argued that the gates should be preserved. As the preserved gates made it difficult to channel urban traffic, it was necessary to build rotaries around the gates [3] (p. 76). While urban planning in 1900 and 1901 focused on the construction of Japanese government districts and residential districts in Taipei inner city, the 1905 plan aimed to connect newly constructed Japanese government and settlement areas in the east with the original Taiwanese regions in the west. Decisively, the demolition of city walls integrated three urban districts—the so-called Sanxijie of Taipei inner city, Dadaocheng, and Banka-using modern urban technologies, including the grid system. Streets were improved throughout the Taipei region. The northwestern section of the inner city was reorganized into blocks with newly constructed orthogonal roads, while new streets were introduced to the undeveloped area between Dadaocheng and Banka. The Municipal Reform Project for Taihoku City (台北市區計畫) continued until 1932, when the Great Taihoku City Plan was announced. The project developed basic urban infrastructures for the modern city of Taipei $[2,14,16]$.

After 1910, the official name of Seoul was changed from Hansungbu to Keijobu. In 1912, the Keijo Civil Engineering Office promulgated the Keijo Urban Improvement Plan, which set out to straighten and widen the 29 lines [50]. It was modified, with the addition of 15 lines, in 1919. During the period up to 1929, JGGK invested 5,792,000 won and constructed $21.3 \mathrm{~km}$ of road in total [51] (p. 164). The initial Keijo Urban Improvement Plan (Figure 8) had two major characteristics.

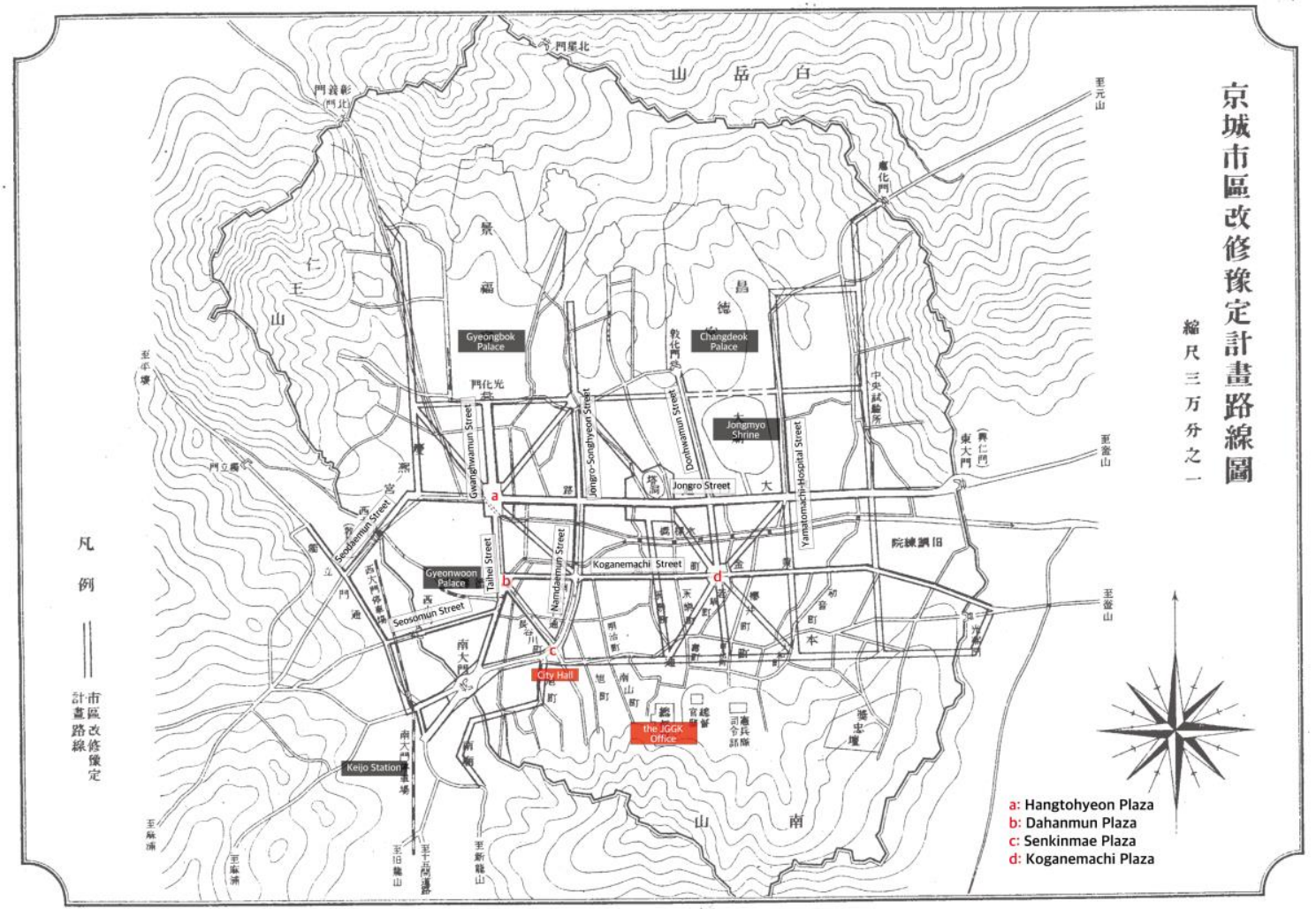

Figure 8. The Keijo Urban Improvement Plan in 1912 (source: Author's edit, Chosensodofukanbou [39]).

The grid system, with five north-south streets and four west-east streets, and the radial road system around five centers. (a-e) The west-east roads, apart from the sixth road (f), designed to link Changeuk Palace with Jongmyo Shrine, had been main city roads since the Joseon Dynasty. By contrast, 
the north-south roads, apart from Namdaemunro Street, were new. In contrast to the Hansungbu road system, which was organized around west-east roads (Figure 3), the Keijo Urban Improvement Plan focused on the grid system by constructing new north-south main roads. The most radical element of this plan was the radial road system around Koganemachi Plaza. This was ultimately never built because the Japanese settlers who owned the planned site for the plaza and the roads rejected the design. The radial road system was ultimately excluded from the amendment plan of 1919 (Figure 9) [5] (pp. 17-24).

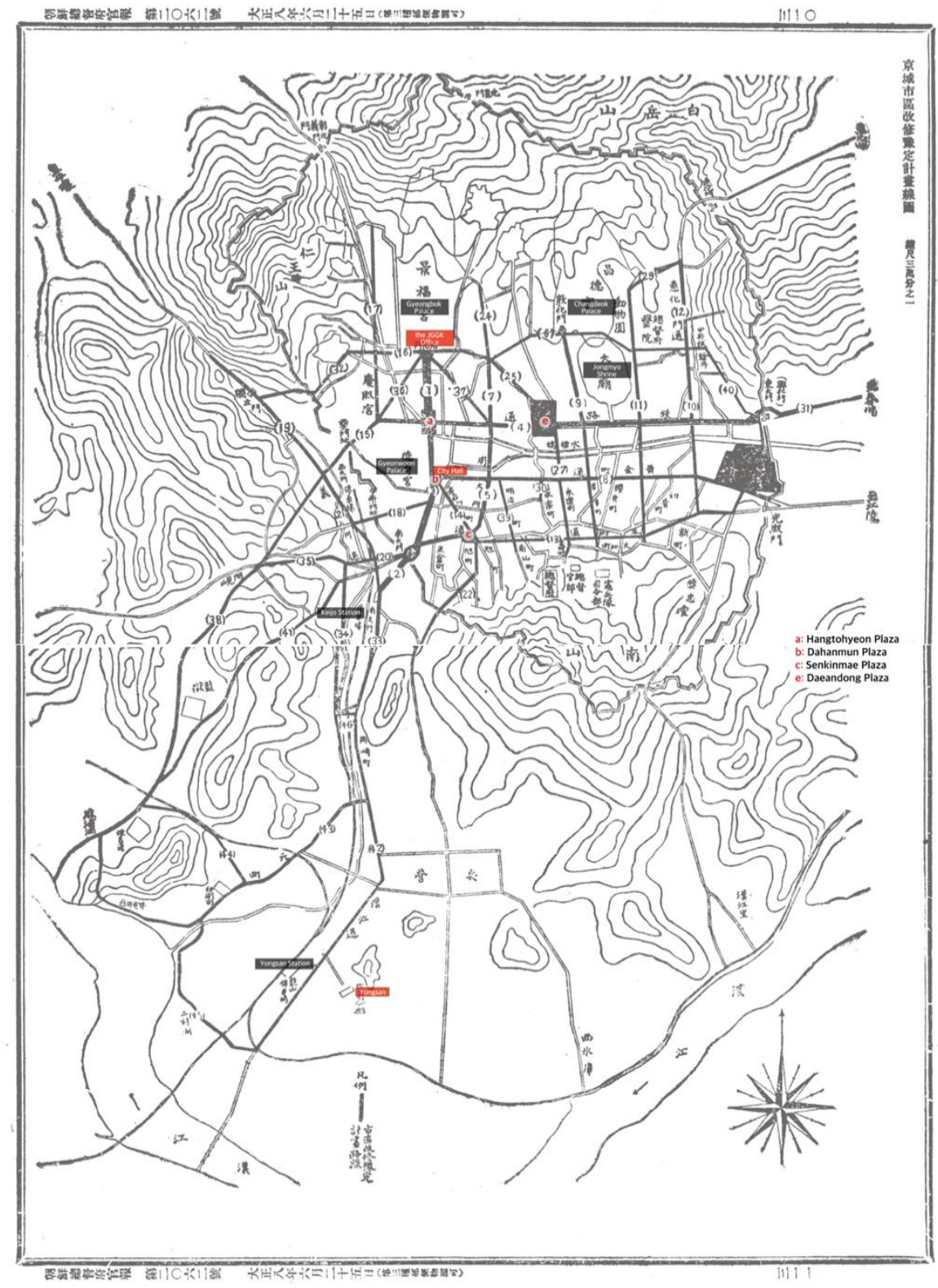

Figure 9. The modified Keijo Urban Improvement Plan in (source: Author's edit, Chosensodofukanbou [40]).

In the 1910s, the Keijo Urban Improvement Plan focused on improving the streets that connected villages to the south, where many Japanese people lived, with the traditional center of Seoul in the north. After the initial plan was modified in 1919, its primary focus became the improvement of streets to the north of Jongro Street $[4,5,21,52]$. This was due to the relocation of government facilities, including JGGK and the Keijofu offices, from Namsan Hill to central Seoul. Consequently, the civic center of Seoul was relocated from Namchon, where the JGGK office was located during the early years 
of colonization, to Bukchon. The 1919 amendment plan also included outbound roads to the outskirts of Seoul, such as Mapo and Yongsan. The map below shows the Seoul city plan, enlarged to include south-western areas. The Keijo Urban Improvement Plan functioned as the basic urban planning map of Seoul until 1936, when the Great Keijo City Plan was announced.

In sum, the 1905 Taihoku City Municipal Reform Project (台北市區計畫) aimed to connect a new civic center built by the Japanese colonizers on the east side with the original Taiwanese settlements in the west. The Keijo Urban Improvement Plan (京城市區改修) created a network to link the Japanese settlement in Namchon with the original civic center of Seoul in Bukchon. Although these urban plans were different in their details, both plans set out to construct urban networks and street improvements. In both cities, new modern blocks incorporated orthogonal road systems; partially radial road systems were built around rotaries, which were urban nodes, such as former city gates or newly built plazas. In addition, engineers enhanced the streets in both cities by expanding road width, refining road conditions, and installing water and sewage systems. It can be assumed that urban planning in Seoul was influenced by previous experiences in Taipei, since the official head of the groups that designed and executed urban planning in Seoul was Mochiji Rokusaburo (對地六三郎) [50] (pp. 193-184), who had previously worked in Taiwan. These two plans were used to provide basic urban planning in both cities until the 1930s, when the Great Taihoku Plan was announced in 1932 and the Great Keijo Plan in 1936.

Although urban planning had similar aims in Taipei and Seoul, differences in the colonization of the two cities had an impact on the execution of modern projects. The first Japanese settlement in Taipei was constructed in a vacant area in Taipei inner city. By contrast, the Japanese settlement in Seoul was located inside the original Korean village at the start of colonization. This made a critical difference between urban changes in Taipei and Seoul, as they moved toward becoming modern colonial cities.

In Taipei, the first Japanese settlement was built around the same time as the colonial government facilities and thus became the center of Taipei City. By the time of the Municipal Reform Project for Taihoku City, the vacant wetland in the east was becoming urbanized on a large scale. Most of the residents of the newly developed eastern districts were Japanese. As the eastern part of colonial Taipei City, where the Japanese settled down from the beginning stage of colonization, was gradually filled with colonial government facilities, hospitals, schools, and Japanese residences, the area had become a civic center.

By contrast, many Japanese merchants and businessmen settled and built neighborhoods in Seoul before the colonization project truly began, after the Russo-Japanese war. Japanese government facilities were temporarily located near the Japanese settlement in 1910. As the Japanese neighborhood Namchon had no geographical or political advantages, it was necessary to move the colonial government facilities, including the JGGK office, to the old civic center in the north. This caused a shift from the south to the north and a spatial separation between the Japanese government-facilities site and the original Japanese settlement.

In conclusion, urban planning in Taipei aimed to integrate the original Taiwanese areas and vacant paddle fields with the new area populated by Japanese people. By contrast, Japanese urban planning in Seoul focused on making inroads into the original Korean civic center Figure 10.

Figure 11 show the Taipei and Seoul urban-planning transformation process. 


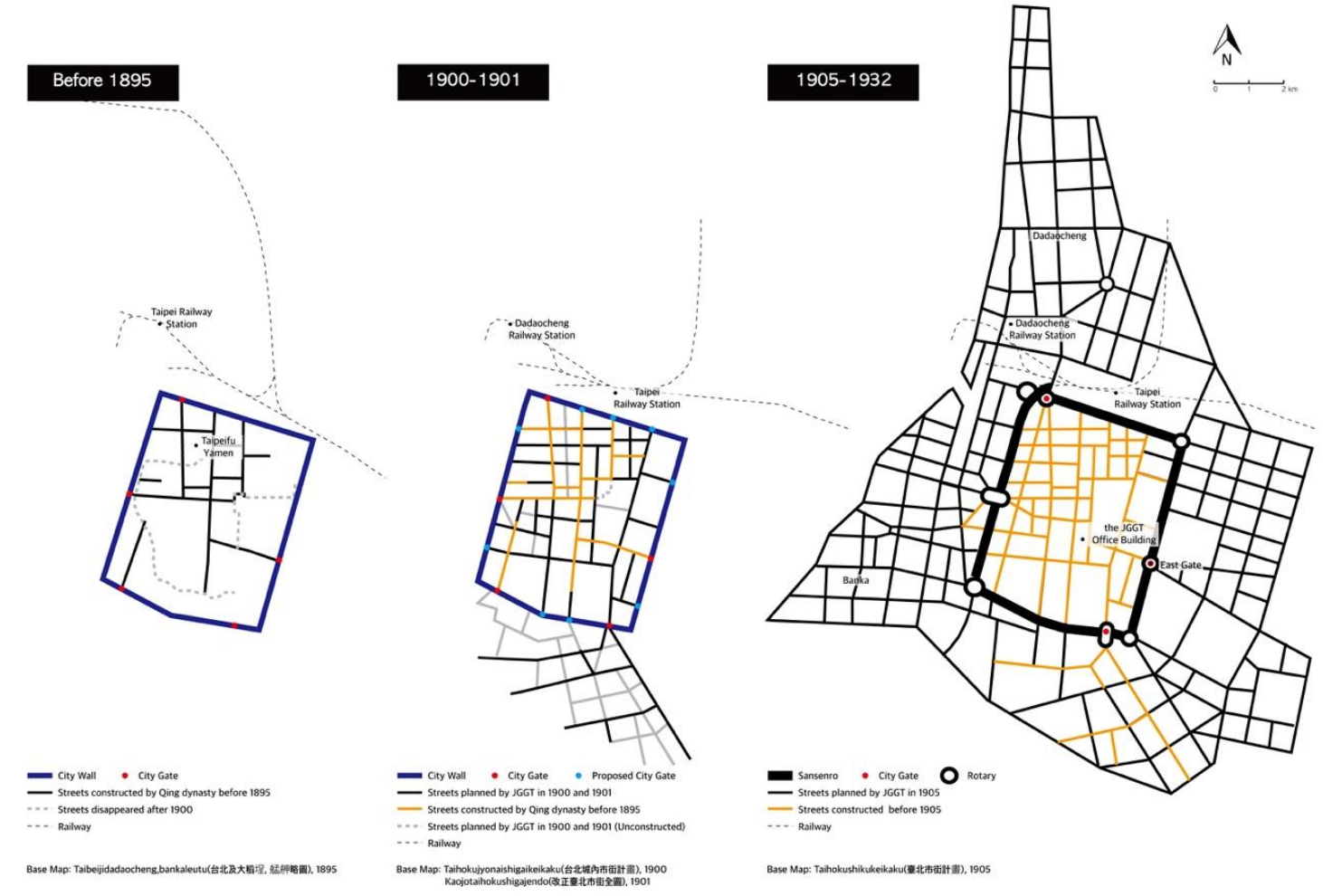

Figure 10. The Taipei urban-planning transformation process before 1932 (source: Author).

\section{$1895-1910$}
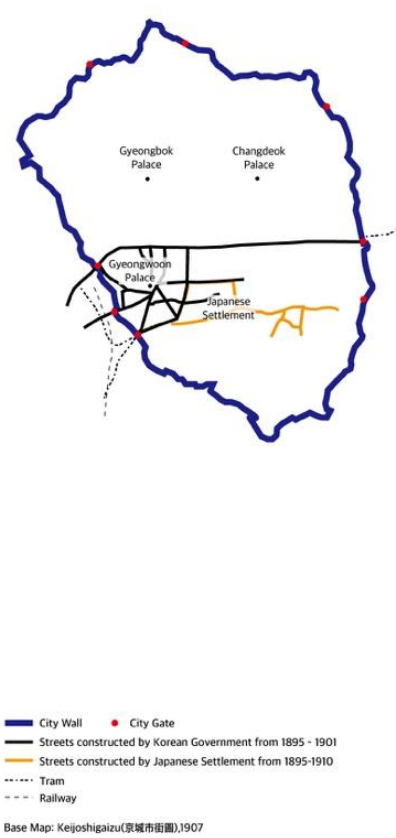

\section{$1912-1919$}
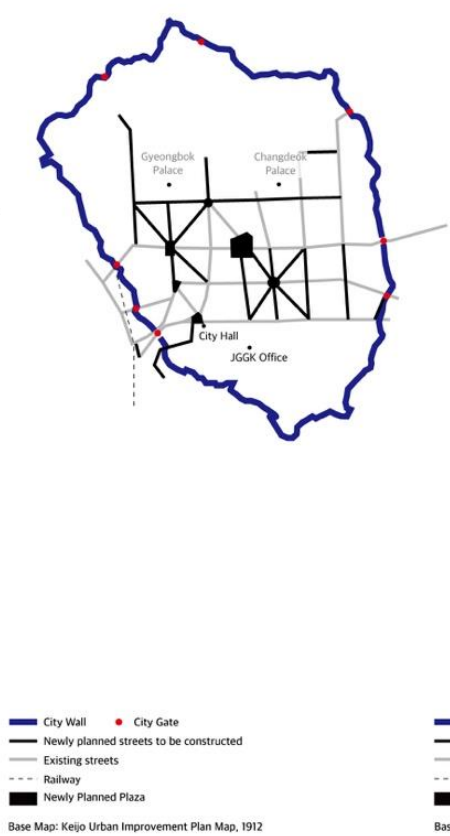

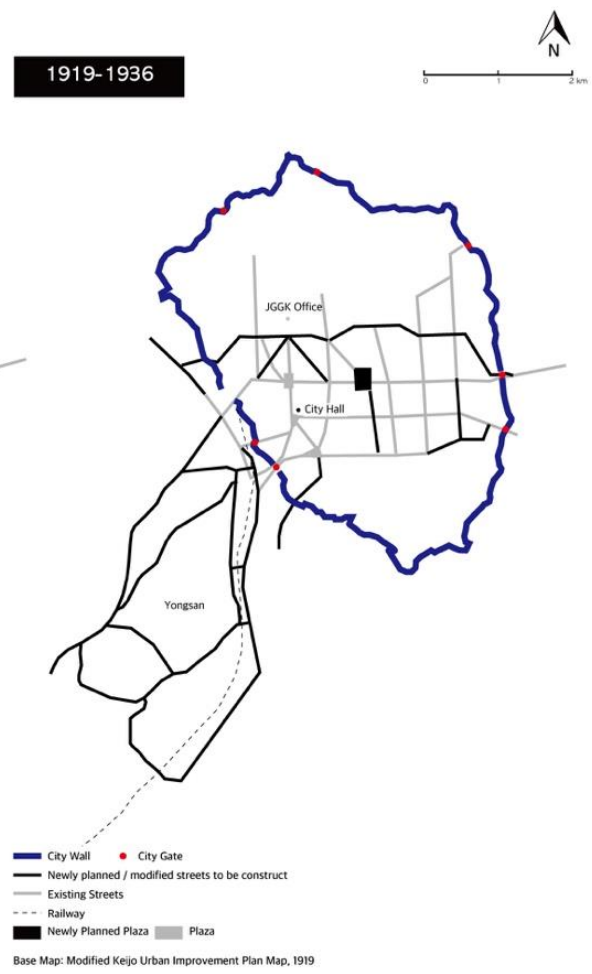

Figure 11. The Seoul urban-planning transformation process before 1936 (source: Author). 


\section{Comparison of Urban Changes in Seoul and Taipei as They Became Modern Colonial Cities 3: Modern Boulevard Showing the Colonizer's Spectacle}

The most tangible achievement of the Taihoku City Municipal Reform Project (台北市區計畫) in 1905 and the Keijo Urban Improvement Plan (京城市區改修) was the construction of modern boulevards in both cities. The representative three-lined ring boulevards (Sansenro, 三線路) [14] are the boulevard in front of the JGGT building in Taipei and Gwanghwamun Boulevard (present-day Sejongro Boulevard) and Taihei Boulevard (present-day Taepyeongro Boulevard) in Seoul [4,21].

In Taipei, the Taipei city wall was displaced by Sansenro, which resembles the boulevards of Paris, having three lanes of traffic separated by a safety island and two lines of trees. As Allen has pointed out, Sensenro transformed Taipei from a traditional Chinese bureaucratic center into a symbolic place of colonial modernity [3] (p. 76). The middle parts of these roads were parkway, planted with a diverse selection of trees: Palm trees in the east, maple trees in the west, cedar trees in the south, and anemone trees in the north. People enjoyed walking in Sansenro, as the popular 1930s Taiwanese song, Guehyiatshiu (Gloomy Moonlight, 月夜愁) describes: “月色照在三線路 風吹微微 等待的人那未 來 The moonlight shines on the three-lined boulevards, the wind blows slightly. It is the future that everyone is waiting for".

East Sansenro (present-day Zhongshan South Road, Figure 14a) was the most significant boulevard, as key modern colonial facilities, including the Taihoku Prefectural Office, Taihoku Hospital, Red Cross Hospital, Taihoku Medical School, and Taihoku New Park were located along east Sansenro (Figure 12).

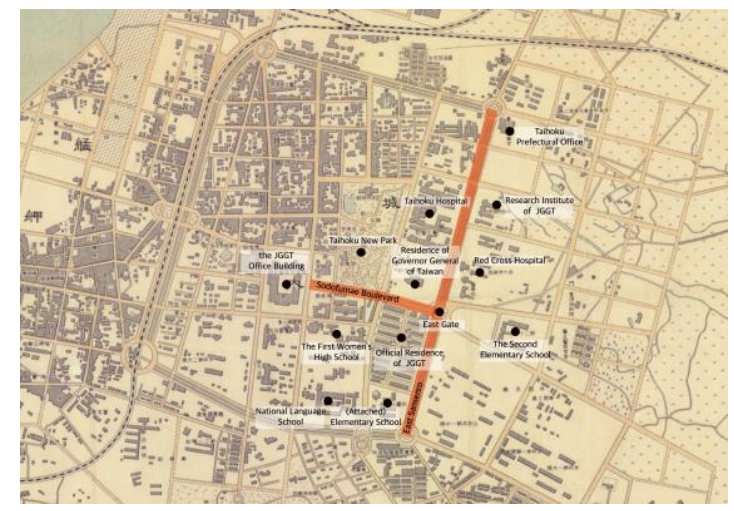

Figure 12. Distribution of colonial modern facilities along the East Sansenro Boulevard (source: Author's edit. The Map and Remote Sensing Imagery Digital Archive Project [37]).

In addition, the Great Taihoku Plan (Figure 13), which expanded developments toward the east further enhanced the dominance of the East Gate and JGGT Boulevard. The modern streetscapes of Taipei City featured straight, wide roads and new Western classical-style buildings. As Wu Pingsheng has explained, "with newly-built boulevards, a scene and atmosphere of modern urbanism was created, revealing the intentions of the colonizer to build a successful colonial city, a new Taipei City" [16] (p. 185).

After 1919, when the symbolic JGGT building, which symbolized Japanese colonial power, was completed, both the boulevard and the East Gate (present-day Ketagalan Boulevard, 凱達格蘭大道, Figures $14 b$ and $15 a, b)$ became more important than the West or North Gates.

Taihei Boulevard was built in 1912 when the Keijo Urban Improvement Plan was implemented in Seoul (Figure 16a). Taihei Boulevard was linked to the north end of Gwanghuamun Boulevard. The new street connected Kyungobok Palace to the South Gate through a straightforward boulevard. Taihei Boulevard was the first street in Seoul to be lined with trees and modern facilities, including the Keijo and Maeil Newspaper buildings. After the construction of Taihei Boulevard, Gwanghuamun Plaza (located at the intersection with Jongro Street) was expanded between 1913 and 1918. In 1924, Seoul City Hall was moved from Namdaemun Street to Taihei Street (Figure 16b). 


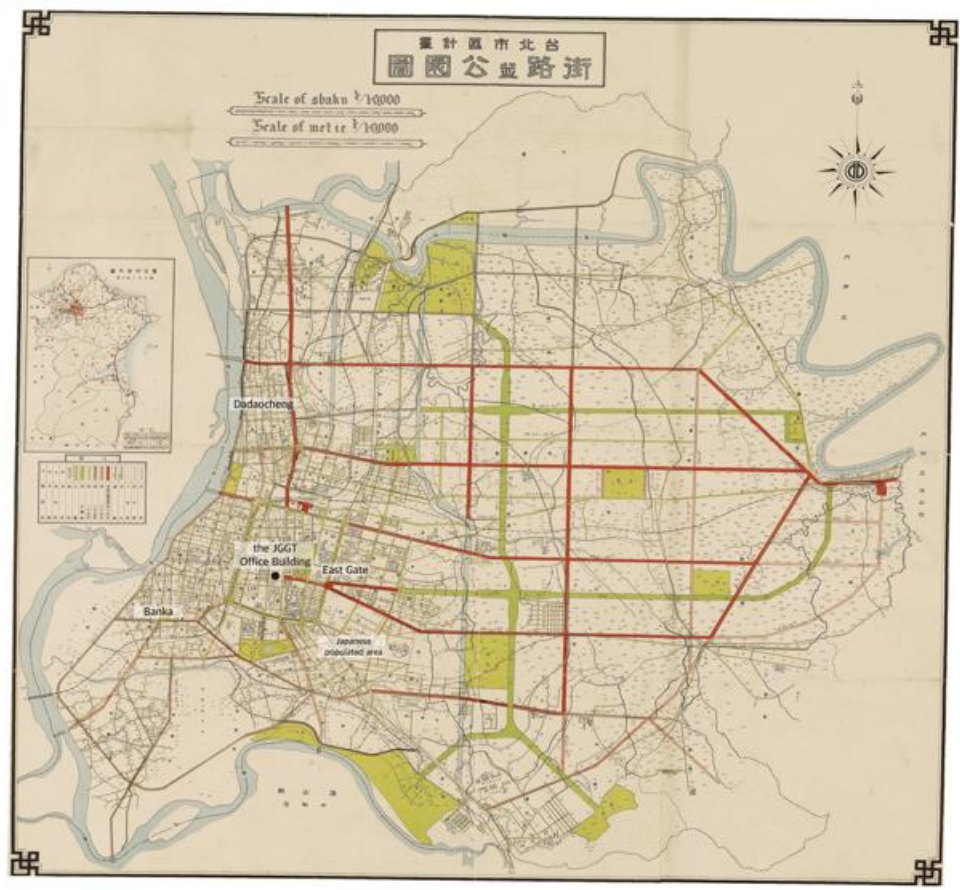

Figure 13. The expansion of colonial Taihoku in 1932 (source: Author's edit. The Map and Remote Sensing Imagery Digital Archive Project [37]).

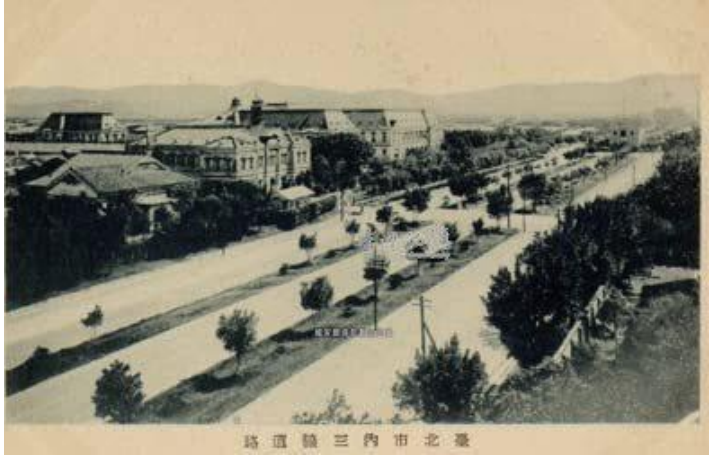

(a)

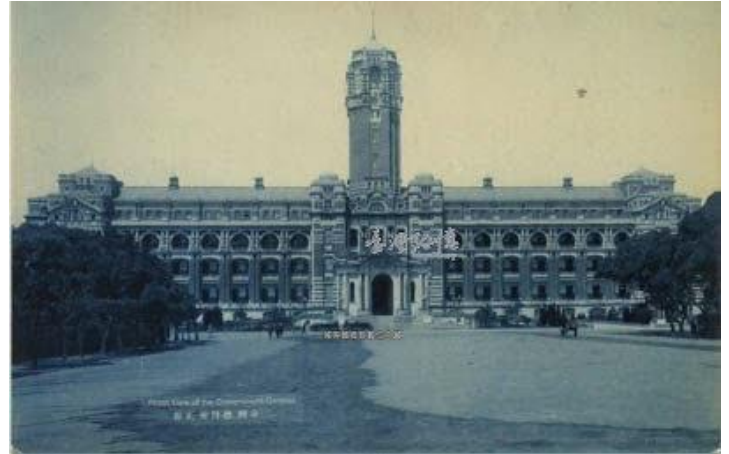

(b)

Figure 14. (a) Streetscape of East Sansenro in the 1920s (source: Taiwan Memories [41], (b) the boulevard in front of the JGGT office building (source: Taiwan Memories [41]).

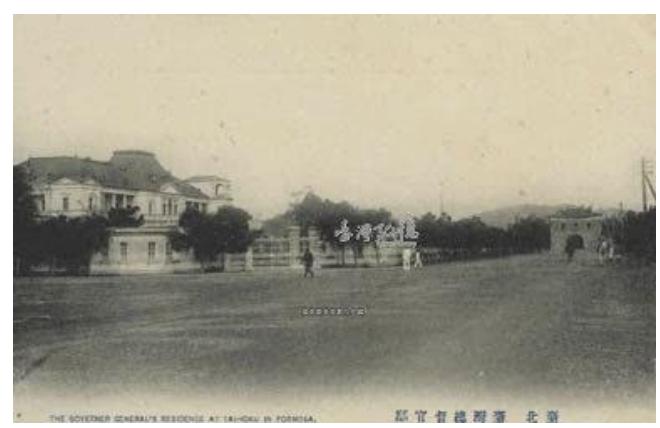

(a)

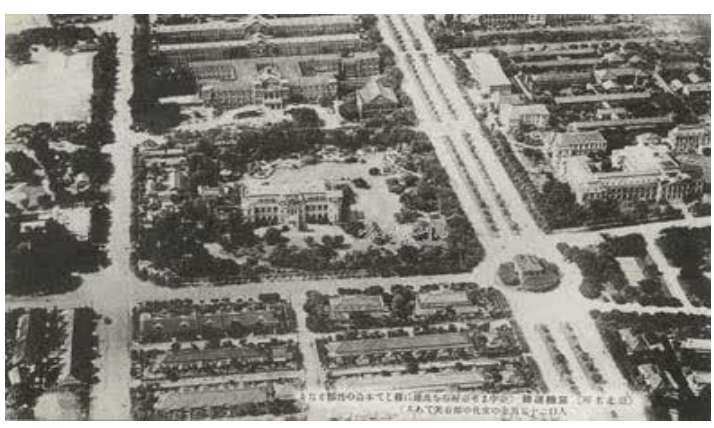

(b)

Figure 15. (a) Streetscape: The boulevard between the East Gate and the JGGT building in the 1910s (source: Taiwan Memories [41], (b) aerial view of East Sansenro and the East Gate (source: Taiwan Memories [41]). 


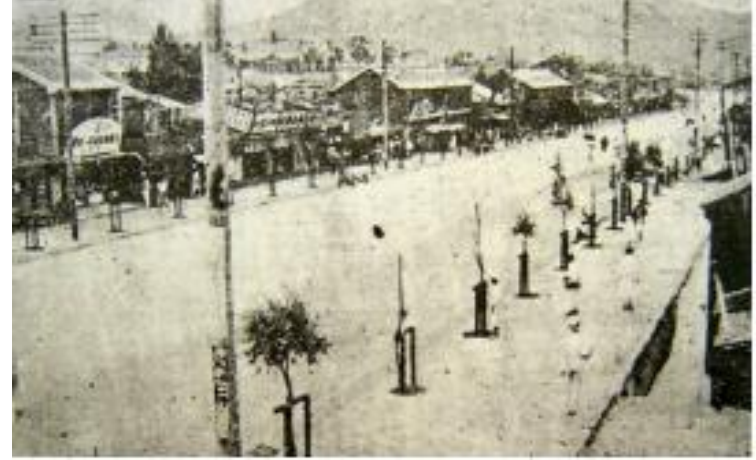

(a)

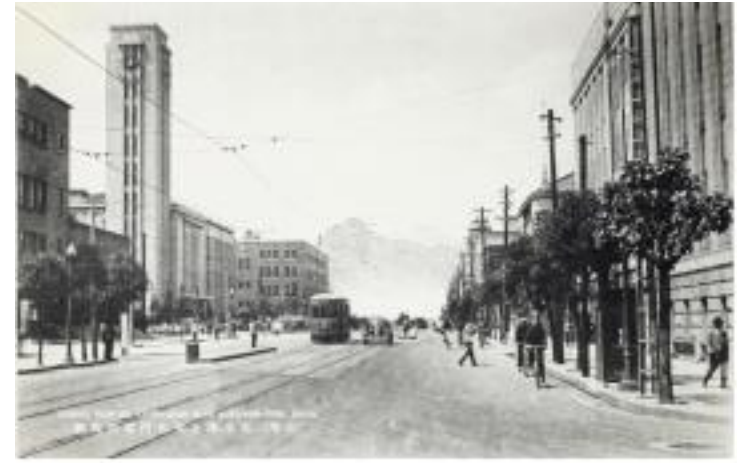

(b)

Figure 16. (a) Taihei Boulevard in 1912, during the urban-improvement project (source: Maeilbhimpo [52]), (b) Taihei Boulevard in the 1930s (source: Seoul Museum of History [38]).

In 1926, the JGGK office building finally opened after seven years of construction (beginning in 1919). Then the project to improve Gwanghwamun Boulevard began. Gwanghwamun Gate, the main gate of Gyeongbok Palace, was moved to the eastern side of the palace (Figure 17a,b). The boulevard was widened to $62 \mathrm{~m}$, making space for a tram line. Street trees were planted along both sides [34] (p. 176), [53,54]. The model of the Gwanghwamun Street Improvement Project included the boulevard in front of the JGGT building [55].

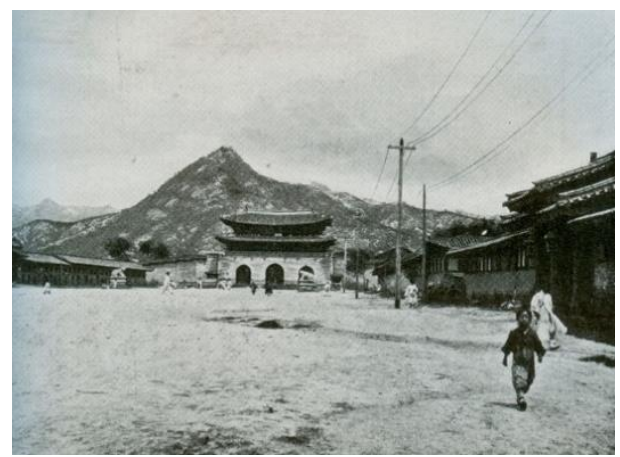

(a)

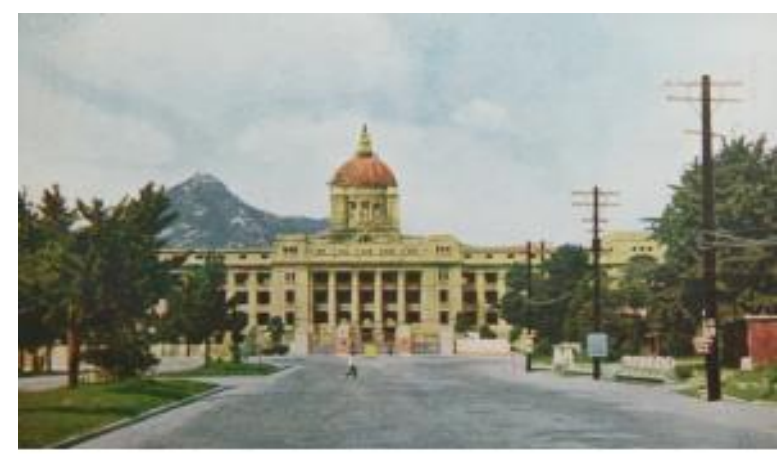

(b)

Figure 17. (a) Gwanghwamun Boulevard before the construction of the JGGK building (source: Seoul Museum of History [38]), (b) Gwanghwamun Boulevard after the demolition of Gwanghwamun Gate (source: Seoul Museum of History [38]).

Finally, in the late 1920s, Gwanghwamun and Taihei Boulevards became modern civic centers, with Western-style office buildings lining the streets. The majestic JGGK building stood at the north end of this modern boulevard, while the route to the South Gate passed Gwanghwamun and Keijofumae Plazas (Figure 18).

Outside the South Gate, Taihei Street intersected with the road to Yongsan and Yeongdeungpo in the Great Keijo Plan (Figure 19). In other words, Gwanghwamun and Taihei Boulevards had become the main north-south axis of Seoul, simultaneously presenting a modern streetscape and an imperial spectacle. However, unlike people in Taipei, the colonized population of Seoul felt repulsed by the construction of Gwanghwamun Boulevard and the JGGK building because builders had demolished the main gate of the Joseon Dynasty Palace. The Korean novelist Park Taewon described the Gwanghwamun Boulevard as an awkward wide and solitary road in his novel A Day in the Life of Kubo the Novelist [56] (p. 138). 


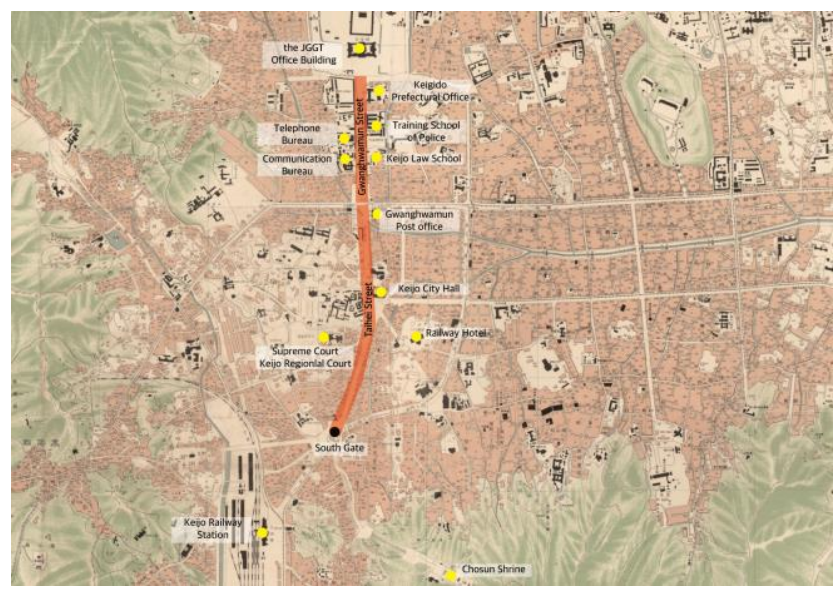

Figure 18. Distribution of modern colonial facilities along Taihei Boulevard (source: Author's edit. Seoul Museum of History [38]).

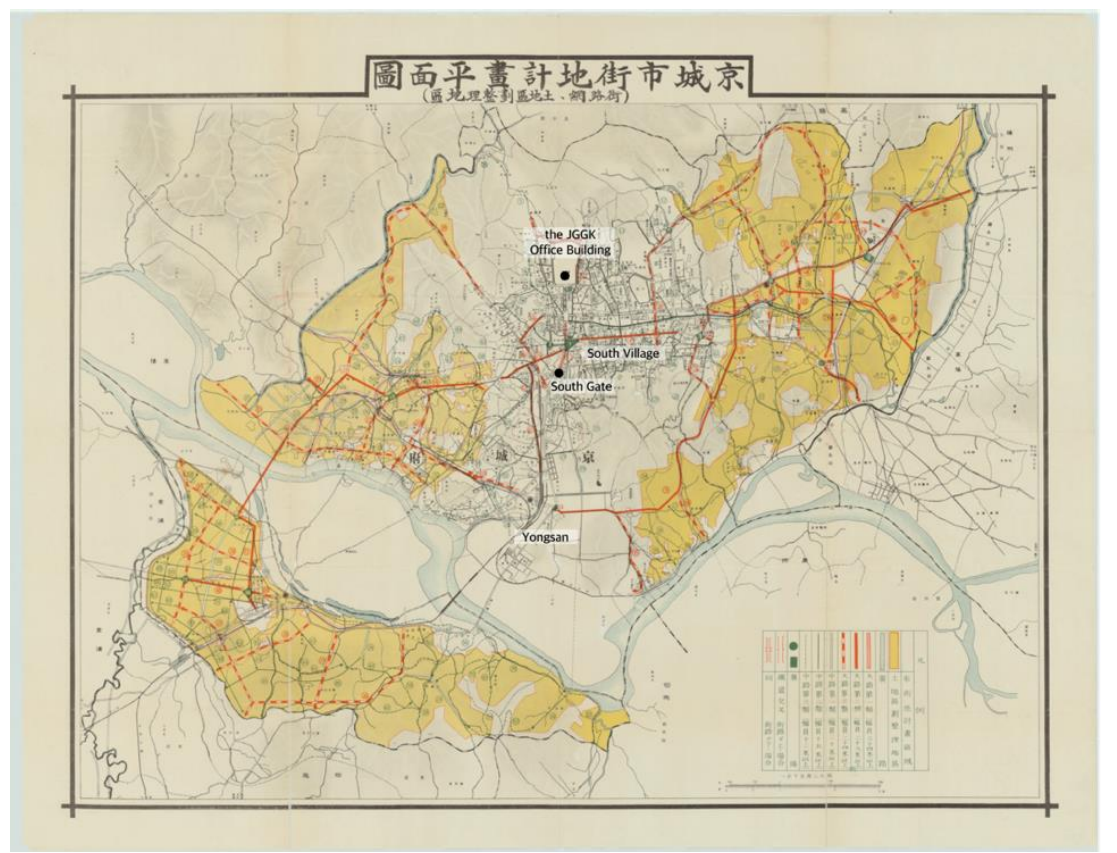

Figure 19. The expansion of colonial Keijo in 1936 (source: Author's edit. Seoul Museum of History [38]).

The modern boulevards built by the Japanese empire in Taipei and Seoul were examples of modern urban planning, as well as colonization projects. The street environment was very similar on the boulevards of Taipei and Seoul. The colonized people who walked those boulevards absorbed the essence of colonial modernity. Both Sodofumae and Gwanghwamun Boulevards were very wide streets, lined with trees, street lamps, utility poles, and modern buildings. At their zenith, they housed Japanese government buildings, displaying their magnificent power. This type of scenery and atmosphere was typical of the main streets of Japanese colonial cities, which included Shinjing (新京), the capital of Manchukuo, as well as Taipei and Seoul. After the liberation of Korea in 1945, Sodofumae Boulevard was renamed Jieshoulu (介壽路), meaning “long live Chiang Kai-shek (蔣介 石)", while Gwanghwamun Boulevard was renamed Sejongro, after Sejong, the fourth Joseon Dynasty king, who invented the Korean alphabet. These boulevards continue to be the most important political and social streets in Taipei and Seoul, despite some minor differences between them. 
After liberation from Japan, Taipei and Seoul endured the Chinese Civil War and Korean War, respectively. When these wars eventually ended, the Taiwanese and Korean governments made every effort to overcome their colonial past and restore native traditions. Japanese-style street and town names were replaced by indigenous but political names, such as Jieshulu and Sejongro [57]. The JGGT and JGGK buildings became Taiwanese and Korean government offices, while other government buildings were also reused [3] (p. 76-77), [58] (p. 86, 277). In the 1960s, the city gates of Taipei, apart from the North Gate, were demolished for not being Chinese enough, and replaced with gates in the North-Palace style [3] (p. 78) (Figure 20).

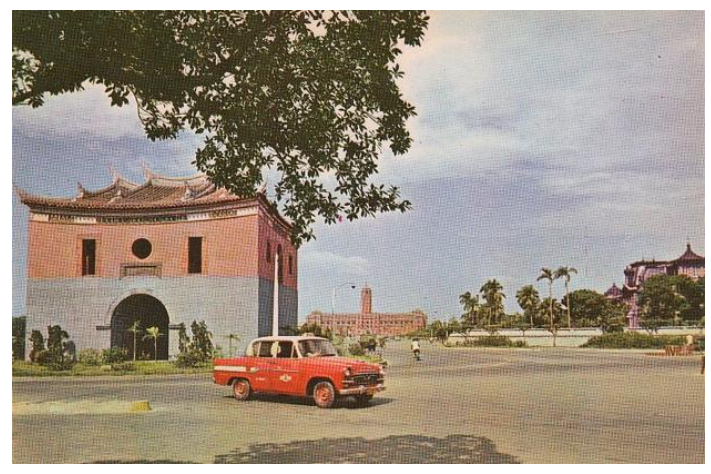

(a)

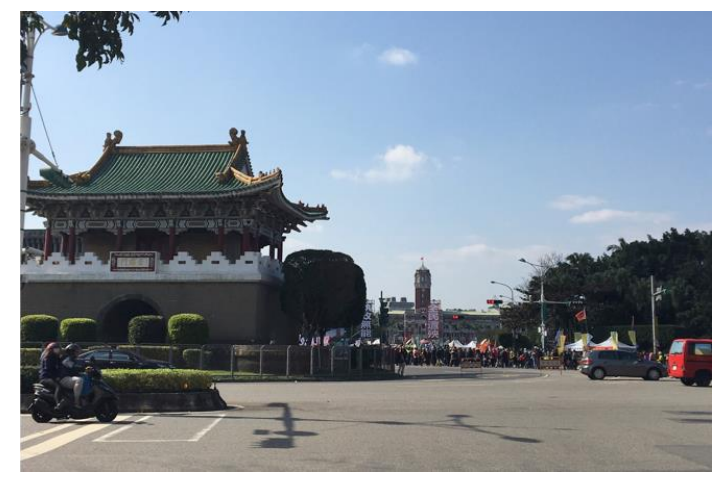

(b)

Figure 20. (a) East Gate and Ketagalan Boulevard before the restoration of the East Gate (source: Taipics [59]), (b) East Gate and Ketagalan Boulevard after the restoration of the East Gate (photo taken by author).

In Seoul, Gwanghwamun Gate was restored in front of the former JGGK building, using the modern material of reinforced concrete (Figure 21a). These renovation projects were seen as government-led projects to recover and restore national legitimacy. In the mid-1990s, there were outstanding issues in both cities. In Taipei, Jieshulu Boulevard was renamed Ketagalan Boulevard in 1996, when Chen Shuibian (陳水扁), who ended the Kuomintang's rule in Taiwan, was the mayor of Taipei. The gate was named in honor of the Ketagalan Taiwanese Aboriginal people who lived in the Taipei area. In Korea, the JGGK building was demolished in 1996 by President Kim Youngsam, on the grounds that it symbolized Japanese imperialism (Figure 21b).

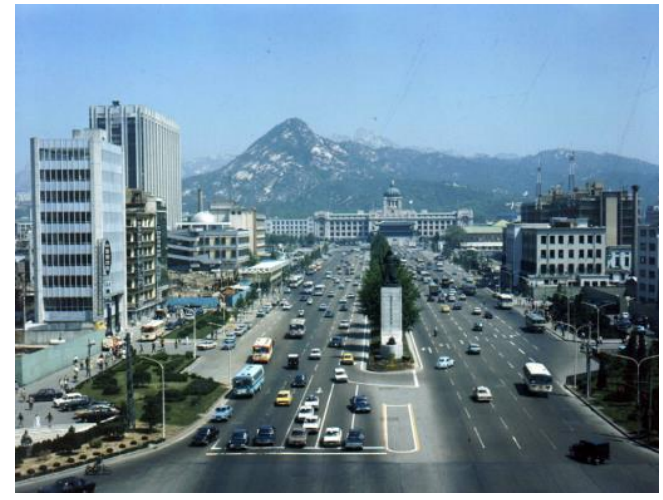

(a)

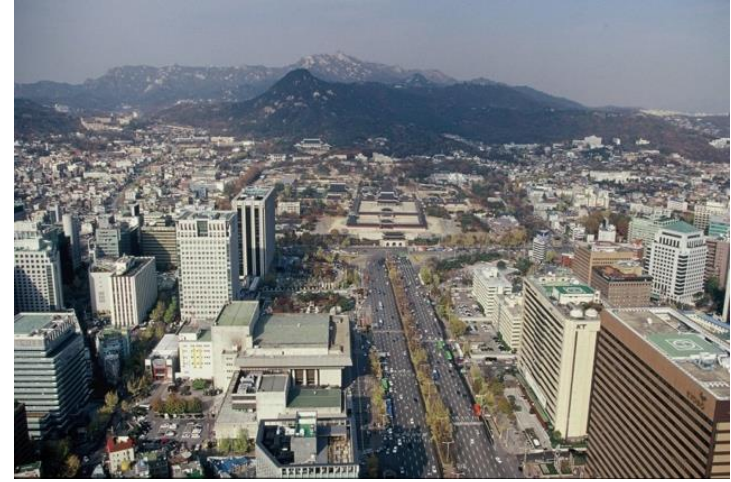

(b)

Figure 21. (a) Sejongro Boulevard (former Gwanghwamun Boulevard) in 1974, after the restoration of Gwanghwamun Gate (source: National Archives of Korea [60] No. CET0042167), (b) Sejongro Boulevard (former Gwanghwamun Boulevard) after the JGGK building was demolished (source: The Seoul Research Data Service [42]). 


\section{Conclusions}

This study set out to discover how the Japanese empire transformed the traditional capital cities of Taiwan and Korea into modern colonial cities by comparing two cities, Taipei and Seoul. The comparison incorporated three strands: The spatial distribution of ethnic groups, urban planning, and the modern boulevard. The process through which Taipei and Seoul were transformed into colonial cities under Japanese rule can be analyzed in the following three ways.

First, at an early stage of colonization, Japanese residential areas influenced the growth of colonial Taipei and Seoul. As colonization progressed, the number of Japanese settlers grew rapidly. It was necessary to build new residential areas for Japanese people, such as the south-eastern village of Taipei and Yongsan in Seoul. In addition, Japanese people moved into older residential areas, such as Banka and Dadaocheng in Taipei and Bukchon in Seoul. Due to a high proportion of Japanese residents in both cities (about 30\% of the population), Japanese people lived in most parts of Seoul and Taipei. Thus, there was little spatial segregation between the colonizer and colonized peoples, unlike the pattern in colonial cities under European rule. Instead, there were three types of areas: Japanese dominated areas, Korean/Taiwanese-dominated areas, and mixed residential areas. The multi-core structure of Taipei and Seoul affected modern Japanese colonial urban planning.

Second, the 1905 Municipal Reform Project for Taihoku City (台北市區計畫) and the Keijo Urban Improvement Plan (京城市區改修), the first examples of modern urban planning executed by Japanese colonial governments in the two cities, aimed to connect dispersed civic centers and to create orthogonal road systems, partially supplemented with shared rotaries and plazas. Although the location of Japanese settlements influenced urban planning in Taipei and Seoul, the details were different in the two cities. The Keijo Urban Improvement Plan had to be modified in 1919 when the colonial government facilities moved. By contrast, the Municipal Reform Project for Taihoku City was carried out without much amendment until the Great Taihoku Plan in 1932, as the colonial municipal center remained in the same place throughout the colonial period. Consequently, the Keijo Urban Improvement Plan focused on improving the traditional center of Seoul, while the Municipal Reform Project for Taihoku City emphasized outward expansion, beyond the demolished city walls.

Third, the modern boulevards, colonial products of modern urban planning, became representative urban places that showcased colonial modernity. The Ketagalan-Zhongshan South Boulevards of Taipei and the Sejong-Taepyeong Boulevards of Seoul continue to be the most important boulevards in Taipei and Seoul. They revealed the power of colonial authority by transforming the traditional urban structures of both cities and offering their citizens a sense of modernity, despite the differences between Taiwanese, Korean, and Japanese people. When the Japanese empire that controlled both cities during the first half of twentieth century was replaced by democratic governments, the two typical modern boulevards of Taipei and Seoul continued to serve as important urban places, where major facilities were located. Many people gather in the plazas beside the boulevards during political and cultural events. The dramatic changes after liberation gave the boulevards an additional meaning: The restoration of national identity to overcome dark memories of colonial power. These boulevards have been transformed from symbolic places that displayed colonial modernity during the first half of the twentieth century into representative places that showcase democracy in Taiwan and South Korea.

In conclusion, along with the boulevards, much of the urban space and spatial structure developed during the Japanese colonial era can still be seen in Taipei and Seoul, even though many buildings were demolished to clear away the remnants of Japanese colonialism for urban development. The old civic centers of Taipei and Seoul represent urban transformation, demonstrating both colonization and restoration processes in two modern cities. Furthermore, the living environments designed during the colonial period to narrate urban history continue to be essential parts of present-day Taipei and Seoul. For instance, the Japanese residential areas, including the Qing-Tian Jie (靑田街) in Taipei [61] and the Hu-Am Dong (厚岩洞) in Seoul [61], are well preserved. These places have been placed in the spotlight by urban regeneration in the 21st century. However, despite their importance, our knowledge of colonial-era urban structure and artifacts remains fragmentary. Some colonial heritage is under threat 
of demolition because many Koreans (and some Taiwanese) still harbor hostility toward the colonizer, Japan. Comparative studies of Taipei and Seoul can help us understand Japanese colonial modern cities, which differ in many respects from Western colonial cities. Both cities were modernized with introduction of modern urbanization system and technologies; however, at the same time, they showed the characteristics of colonial cities including spatial distribution by ethnic groups, multi-core urban structure, and the modern boulevard showing imperial spectacle in common. It means that the present urban conditions of two cities are very complicated, because the areas of the colonizer and the colonized were not separated and the modern transformation process has continued based on colonial urban planning after the liberation. Thus, such studies can unearth the meaning and value of colonial remnants including urban structure and artifacts for the sustainable future of each city, because it is not impossible to totally erase the colonial remnants of each city.

Funding: This work was supported by the Ministry of Education of the Republic of Korea and the National Research Foundation of Korea (NRF- 2017S1A5B5A07062062).

Acknowledgments: I would like to thank Editage (www.editage.co.kr) for English language editing.

Conflicts of Interest: The authors declare no conflict of interest.

\section{References}

1. Jung, T.H. Extending the Horizon for Understanding the History of International Relations in Northeast Asia (Korea-Taiwan-Japan Relations) through the Verification of a Hiatus between Historical Recognition and Research Objects. J. Asiat. Stud. 2013, 56, 9-22.

2. Su, S.B. Visible and Invisible Taipei (臺北看得見的看不見與), 1st ed.; Qunxue (群學): Taipei, Taiwan, 2010.

3. Allen, J.R. Taipei: City of Displacements, 1st ed.; University of Washington Press: Seattle, WA, USA, 2012; Available online: https://www.jstor.org/stable/j.ctvcwn62d (accessed on 10 April 2020).

4. Kim, B.Y. Jibaewagonggan: Sikminjidosigyeongseonggwajegukilbon, 1st ed.; Mungakgwajisungsa: Seoul, Korea, 2009.

5. Yum, B.K. Seouluigiwongyeongseonguitansaeng: 1910-1945 Dosigyehwoikeurobongyeongseonguiyeoksa, 1st ed.; Idea: Seoul, Korea, 2016.

6. Coyer, T. A tale of Two Ex-Colonies: Korea and Taiwan, Asian Times. 2020. Available online: https: //asiatimes.com/2020/03/a-tale-of-two-colonies-korea-and-taiwan/ (accessed on 10 April 2020).

7. Wang, C.H. Dark Tourism through the Rebels' City-An Alternative Guide for Taipei: Sanzini; Korean trans.: Seoul, Korea, 2017.

8. Go, C.J. Iljegangjeomgiganamgin'bulpyeonhanyusan' ... Jeoksangaokuimiraeneun? SBS NEWS. Available online: https://news.sbs.co.kr/news/endPage.do?news_id=N1005139222 (accessed on 10 April 2020).

9. Goto, Y. Comparative Study about Shikukaisei Urban Improvement as Planning System and Technique at KEIJO 1912-1937 (Seoul; at present) and TAIHOKU 1895-1932 (Taipei; at present). J. City Plan. Inst. Jpn. 1999, 34, 865-870. [CrossRef]

10. Goto, Y. Comparative Study about the City Planning Systems in Taiwan (for the Years 1895-1945) and Korea (for the Years 1912-1945) under Japanese Rule. In Proceedings of the 18th International Planning History Society Conference, Yokohama, Japan, 15-19 July 2018; Available online: http://iphs2018.jp/wordpress/wpcontent/uploads/2018/06/Final-Program-IPHS2018_180623.pdf (accessed on 10 April 2020).

11. Shin, G.W.; Robinson, M.E. Colonial modernity in Korea, 1st ed.; Harvard University Asia Center: Cambridge, MA, USA, 1999.

12. Lee, S.S. The Government-General of Joseons City Planning policy deliberative committee: The government-general of Joseons public works committee and the urban district planning committee. J. Korean Hist. 2006, 134, 221-264.

13. Koshizawa, A. Planning history of Taipei under the Japanese rule, 1895-1945. Pap. Res. Meet. Civ. Eng. Hist. Jpn. 1987, 7, 121-132. [CrossRef]

14. Huang, W.T. Rizhishidai (1895-1945) Taipeishizhijindaidushijihua (日治時代 (1895-1945) 台北市之近代都市計 劃), 1st ed.; Taiwandushishiyanjiushi (臺灣都市史究室): Taipei, Taiwan, 1997; Volume 2.

15. Goto, Y. A Study about the introduction of modern city planning in Taipei under Japanese rule. J. City Plan. Inst. Jpn. 2009, 44, 859-864. [CrossRef] 
16. Wu, P.S. Phantasmagoria: A Study on the Transformation of Urban Space in Colonial Taiwan-Tainan and Taipei, 1895-1945. Ph.D. Thesis, National Cheng Kung University, Tainan, Taiwan, 2007. Available online: https://hdl.handle.net/11296/6n865z (accessed on 10 April 2020).

17. Son, J.M. (Iljegangjeomgi)dosigyehwoikyeongu, 1st ed.; Iljisa: Seoul, Korea, 1990.

18. Son, J.M. (Hangukgaehanggi)dosibyeonhwagwajeongyeongu: Gaehangjang.gaesijang.jogye.georyuji, 1st ed.; Iljisa: Seoul, Korea, 1994.

19. Lee, T.J. The main agents and directivity of urban improvement from 1896-1940. Hanguksaron 1997, 37, 181-206.

20. Kim, G.W. The urban planning of Daehan Empire period-City improvement of Hansungbu. Hyangtoseoul 1990, 50, 95-122.

21. Henry, T.A. Assimilating Seoul: Japanese Rule and the Politics of Public Space in Colonial Korea, 1910-1945, 1st ed.; University of California Press: Oakland, CA, USA, 2014; Available online: https://www.jstor.org/stable/10. 1525/j.ctt5hjhxq (accessed on 10 April 2020).

22. Abu-Lughod, J.L. Tale of Two Cities: The Origins of Modern Cairo. Comp. Stud. Soc. Hist. 1965, 7, 429-457. Available online: www.jstor.org/stable/177561 (accessed on 10 April 2020).

23. Chun, W.Y. Chonro and honmachi-Two faces of downtown shopping area in Seoul. Yŏksa Wa Hyŏnsil Q. Rev. Korean Hist. 2001, 40, 163-193.

24. Kim, J.G. A critical assessment on the colonial duality of Kyungsung (Keijo). J. Seoul Stud. 2012, 38, 1-68. Available online: http://www.dbpia.co.kr/journal/articleDetail?nodeId=NODE01722469 (accessed on 10 April 2020).

25. Historical Demography/Research Center for Humanities and Social Sciences, Academia Sinica. Available online: https://www.rchss.sinica.edu.tw/popu/operill.html (accessed on 22 January 2020).

26. Taiwan Database for Empirical Legal Studies. Available online: http://tcsd.lib.ntu.edu.tw (accessed on 22 January 2020).

27. Taihokushiyajusho. Taihokushitoukeisho; Taihokushiyajusho: Taihoku, Taiwan, 1933.

28. Korean Statistical Information Service. Available online: www.kosis.kr (accessed on 22 January 2020).

29. Chosensodoufu. Chosenshowajyunenkokujeichosasho; Chosensodoufu: Keijo, Korea, 1935.

30. Lee, J.S. Neighborhood and population changes in Seoul during the period of Japanese colonization-Focusing on residential segregation by ethnic groups from 1925 to 1935. Hyangtoseoul 2007, 69, 301-348.

31. Taihokushi. Taihokujyunenshi, 1st ed.; Taihokushi: Taihoku, Taiwan, 1930; Available online: https://ndlonline. ndl.go.jp/\#!/detail/R300000001-I000000761891-00 (accessed on 10 April 2020).

32. Taihokushi. Taihokusiseinijyunenshi, 1st ed.; Tchengwenchubanshe: Taipei, Taiwan, 1985.

33. Chen, Z.-X. 25Taibeishizhi, 2nd ed.; Taibeishi: Taipei, Taiwan, 1997.

34. Keijofu. Keijotoshikeikakuchosasho, 1st ed.; Keijofu: Keijofu, Korea, 1928.

35. Keijofu. Keijofushi, 1st ed.; Keijofu: Keijofu, Korea, 1936.

36. Seoulsisapyeonchanwiwonhwoi. Seoulyukbaeknyeonsa, 1st ed.; Seoulsi: Seoul, Korea, 1981.

37. The Map and Remote Sensing Imagery Digital Archive Project. Available online: http://gis.rchss.sinica.edu. tw/mapdap (accessed on 22 January 2020).

38. Seoul Museum of History. Available online: http://museum.seoul.go.kr/archive (accessed on 22 January 2020).

39. Chosensodoufufkanbou, 6 November 1912. Available online: https://www.nl.go.kr/NL/contents/ N20302010000.do (accessed on 21 February 2020).

40. Taiwan Memory. Available online: https://tm.ncl.edu.tw/) (accessed on 22 January 2020).

41. The Seoul Research Data Service. Available online: http://data.si.re.kr/ (accessed on 22 January 2020).

42. Shiba, Y.; Im, D.-H. Junggukdosisa, 1st ed.; Sin, T.-G., Translator; Seogyeongmunhwasa: Seoul, Korea, 2008.

43. Chang-Rong, L.I.; Ta-Wei, K.U.; Yu-Fu, Y.A.; Hsuan-Chu, C.H.; Jui-Che, T.U. Design Aesthetics of Taipei City Walls: Aesthetic Principles and Culture Preservation. Bull. Jpn. Soc. Sci. Des. 2016, 62, 82-88.

44. Taibeijidadaocheng, Bankaleutu (台北及大稻埕, 艋舺略圖). 1895. Available online: https://twh.boch.gov.tw/ world-memory/tw_detail.aspx?id=340 (accessed on 10 April 2020).

45. Lee, G.-C. Reorganization of Urban Spaces in Seoul during the Great Han Empire Period. Ph.D. Thesis, Seoul University, Seoul, Korea, 2010.

46. Jeong, S.-I. A Study on the Changing of Urban Spatial Structure in Seoul- Focused on Daehan Empire Period. Master's Thesis, Hanyang University, Seoul, Korea, 2005. 
47. Lee, Y. Hangsungbuuijakeunilbon: Jingogaehokeunhonmachi, 1st ed.; Spacetime: Seoul, Korea, 2015.

48. Yang, S.-W. IljesidaeIlboninuiYongsanJeomyugwajeong. In Boijianneunyongsanboineunyongsan, 1st ed.; The Institute of Seoul Studies, Ed.; Mati: Seoul, Korea, 2009; pp. 13-37.

49. Yum, B.-K. Urbanizing Gyeongseong during the 1910s-1920s: Captured in "Remembering Twenty Years of Gyeongseong City Street Improvement Project". Art History Forum 2017, 44, 177-205. [CrossRef]

50. National Archives of Korea. Iljemunseohaeje: Tomokpyeon, 1st ed.; National Archives of Korea: Daejeon, Korea, 2010.

51. Kim, Y. A Study on Changes and Characteristics of Everyday Life during the Japanese Colonization of Korea-Focused on 'Keijo' Area. Ph.D. Thesis, Yonsei University, Seoul, Korea, 2000.

52. Anonymous. Soudofukaranandaemonheichokusennodaigairo. Keijonippo, 15 June 1927.

53. Anonymous. Gwanghwamundorinoryokka. Chosen Shimpo, 29 April 1934.

54. Anonymous. Byeonmokjeonghwahalgwanghwamuntongsamsibokanueidaeganseondoro. Maeilshinpo, 6 September 1926.

55. Park, T.-W. Soseolgagubossiuniilil ( $A$ Day in the life of Kubo the Novelist), 1st ed.; Munhakgwajisungsa: Seoul, Korea, 2005.

56. Anonymous. Sajin: Namdaemuneseogwanghwamunejihaneunsigugaejeong. Maeilshinpo, 22 August 1913.

57. Lee, H.-K. 'Difficult Heritage' in Nation Building: South Korea and Post-Conflict Japanese Colonial Occupation Architecture, 1st ed.; Palgrave Macmillan: London, UK, 2019. [CrossRef]

58. Taipics. Available online: www.taipics.com (accessed on 1 April 2018).

59. National Archives of Korea. Available online: http://archives.go.kr (accessed on 22 January 2020).

60. Kuo, Y.; Takada, M.; Kanki, K.; Yasueda, H.; Huang, L.-S. A study on the utilization of the Japanese style houses on Qing-Tian Street as well as their extension and remodeling after the Japanese colonial period: A study on the transformation of the living space of Japanese-style houses in Taiwan. J. Archit. Plann. 2008, 628, 1189-1196. [CrossRef]

61. Lee, K.-A. Gyeongseonguijutaekji; Jib: Seoul, Korea, 2019.

(C) 2020 by the author. Licensee MDPI, Basel, Switzerland. This article is an open access article distributed under the terms and conditions of the Creative Commons Attribution (CC BY) license (http://creativecommons.org/licenses/by/4.0/). 